\title{
O desenvolvimento do contrato de seguro no direito civil brasileiro atual*
}

\section{Fábio Siebeneichler de Andrade**}

Resumo: O presente trabalho tem por objetivo examinar questões controvertidas, no plano doutrinário e jurisprudencial, do contrato de seguro, por força do desenvolvimento dado ao tema nos dez anos de vigência do Código Civil brasileiro de 2002 .

Palavras-chave: contrato de seguro, o código civil brasileiro, os direitos do segurado, os direitos de segurador.

\section{Desarrollo del contrato de seguro en el actual derecho civil brasileiro}

Resumen: Este estudio tiene como objetivo examinar las cuestiones controvertidas, en la doctrina y la jurisprudencia, del contrato de seguro, con ocasión del desarrollo de esta materia en los diez años de vigencia del Código Civil brasileño de 2002.

Palabras clave: contrato de seguro, código civil brasilero, deberes del asegurado, deberes del asegurador,

* Fecha de recepción: 30 de diciembre de 20I4. Fecha de aceptación: I6 de marzo de 2015.

Para citar el artículo: F. S. DE ANDRADE. "O desenvolvimento do contrato de seguro no direito civil brasileiro atual”, Revista de Derecho Privado, Universidad Externado de Colombia, n. ${ }^{\circ} 28$, enero-junio de 2015, pp. 203-236. DOI: I0.1860I/oI234366.n28.08

** Doctor en derecho por la Universidade de Regensburg, Alemania. Profesor titular de Derecho Civil y del programa de posgrados de la Pontifícia Universidade Católica do Rio Grande do Sul [PUC-Rs]. Abogado em Porto Alegre, Brasil. Contacto: fabio.andrade@camposadvocacia.com.br 


\section{Development of the insurance contract in the Brazilian civil law}

Aвstract: The objective of the research is to identify and analyse the problematic issues of insurance contracts that have emerged after ten years of enforcement of the Civil Code of $\mathbf{2 0 0 2}$, either in the doctrine and the jurisprudence.

Keywords: Insurance contract, Brazilian Civil Code, duties of the insured, duties of the insurer.

Resumo: Introdução. I. A natureza do contrato de seguro e seu enquadramento no direito civil brasileiro. A. Natureza jurídica e os elementos essencias do contrato de seguro no códgico civil de 2002 . B. Reflexões sobre o enquadramento do contrato de seguro. II. Temas controvertidos no âmbito dos deveres contratuais. A. A relativização da mora do segurado no pagamento do prêmio. B. O dever do segurado de abster-se quanto ao agravamento dos riscos e sua conseqüência para o contrato de seguro. C. A extensão do dever de informar do segurado. I. O dever de informar do segurado quanto a riscos preexistentes. 2. O dever de informar do segurado quanto à agravação dos riscos. III. Questões controvertidas quanto ao cumprimento pelo segurador de seu dever de garantia. A. O pagamento pelo segurador. B. A sub-rogação do segurador na posição jurídica do segurado. Conclusão.

\section{Introdução}

Dentre o amplo espectro de vínculos contratuais típicos regulados pelas codificações oitocentistas, o contrato de seguro foi um dos que mais sofreu modificações.

Esta circunstância decorre de vários fatores, que podem ser, em essência, agrupados nos seguintes pontos: a elevação do risco de principal pressuposto do contrato de seguro para o patamar de fundamento da teoria da responsabilidade civil. Agregue-se a esta primeira razão, o incremento extraordinário da responsabilidade civil, o que conduziu ao incremento da necessidade de utilização do contrato de seguro como instrumento de prevenção de prejuízos na esfera negocial e pessoal. Acrescente-se que, por força da extraordinária difusão do contrato de seguro, ele conhece uma profunda regulação pública, tendo ainda a atividade securitária uma regulação estatal.

O Direito brasileiro, em linha com outros ordenamentos jurídicos, experimentou as alterações na regulação e concepção do contrato de seguro, desde sua primeira codificação civil, de ı 9 6. Neste Código Civil, predominava o delineamento clássico ao contrato de seguro, como, por exemplo, a concepção indenizatória da figura contratual, a regulação dos seus principais pressupostos - prêmio, risco e interesse -, bem como suas espécies. 
Contudo, ao longo do século xx, a regulação do contrato de seguro no Direito brasileiro extrapolou as molduras da codificação, sendo instituído um sistema nacional de seguros privados, pelo Decreto-lei n. 73/66. Uma das modificações passíveis de referência foi a regulação dos seguros obrigatórios, o que demonstra a intersecção da atuação pública, mediante instrumentos de direito privado, para o fim de tutelar determinados setores considerados intrinsecamente expostos ao risco da atividade.

O Direito brasileiro conheceu, em 2002, um segundo Código Civil, que novamente contemplou a matéria do contrato de seguro. Não seguiu, portanto, a solução de alguns ordenamentos - como o direito alemão - que possui uma lei especial para os seguros.

Em face desta circunstância, e tendo como premissa a indicada relevância do contrato de seguro no Direito brasileiro - e na maioria dos ordenamentos -, reputa-se relevante pontuar as principais alterações elencadas na segunda codificação civil, a fim de propor uma reflexão sobre elas e sobre as soluções estabelecidas pelo codificador brasileiro. Ao mesmo tempo, cumpre situar os dispositivos do contrato de seguro no Código Civil brasileiro de 2002 no âmbito do Direito Privado brasileiro, que possui, por exemplo, uma consolidada legislação de defesa do consumidor (Código de Defesa do Consumidor - Lei n ${ }^{\circ}$ 8.078/90).

Nesses termos, pretende-se expor, numa primeira parte, as disposições relativas à Natureza do Contrato de Seguro e Seus elementos em uma primeira parte; em uma segunda parte, examinar os pontos mais controversos acerca dos deveres contratuais do segurado; na terceira parte, questões conexas ao pagamento da indenização pela seguradora.

\section{A natureza do contrato de seguro e seu enquadramento no direito civil brasileiro}

\section{A. Natureza jurídica e os elementos essencias do contrato de seguro no códgico civil de 2002}

O regime das disposições gerais, elaborada pelo Código Civil de 2002, contempla desde logo um conceito do contrato de seguro no artigo $757^{\mathrm{I}}$, o que configura uma linha aproximativa com a disciplina do artigo I.432 do Código de I9 $6^{2}$. Nos moldes do código anterior, tem-se novamente presentes a definição

I Art. 757. "Pelo contrato de seguro, o segurador se obriga, mediante o pagamento do prêmio, a garantir interesse legítimo do segurado, relativo a pessoa ou a coisa, contra riscos predeterminados.

Parágrafo único. Somente pode ser parte

2 Art. I.432, do Código Civil de r9r6: "Considera-se contrato de seguro aquele pelo qual uma das partes se obriga para com a outra, mediante a paga de um prêmio, a indenizá-la do prejuízo resultante de riscos futuros previstos no contrato”. 
e os elementos do contrato de seguro. Trata-se de uma característica do direito brasileiro, pois nem todas as legislações definem o contrato de seguro 3 .

Do confronto entre as duas definições, cumpre situar a atual codificação no quadro das teorias do contrato de seguro ${ }^{4}$. No direito anterior, definia-se o contrato de seguro à luz da teoria da indenização. Em essência, a finalidade do contrato de seguro no Código Civil de i9i 6 seria a de ressarcir os prejuízos provenientes de certos riscos.

O artigo 757 do Código civil atual consagra, por sua vez, a noção de garantia, caracterizando o contrato de seguro como negócio jurídico de garantia 5 , da parte do segurador, frente a um interesse legítimo do segurado ${ }^{6}$. O fundamento desta corrente é de ordem econômica: procura explicitar o interesse do segurado em prevenir eventuais prejuízos, relativamente a determinados riscos que podem concretizar-se no futuro.

Uma outra questão doutrinária sobre a qual o Código Civil se posiciona concerne a questão de seu caráter unitário ${ }^{7}$. Predomina, também, na disciplina concebida pelo Código Civil, a concepção de o contrato de seguro possuir caráter unitário, na medida em que estabeleceu disposições gerais, para as duas espécies de seguro disciplinadas na codificação, o seguro de dano e o de pessoa, bem como determinou que as suas disposições aplicam-se às leis especiais sobre a matéria, desde que exista compatibilidade (artigo 777).

Há que se ponderar, porém, que o Código civil regula apenas a categoria dos seguros privados, estando excluídos os seguros sociais. No âmbito dos seguros privados, observa-se que o Código adotou uma concepção clássica quanto à classificação dos seguros ${ }^{8}$, fazendo menção apenas às espécies acima indicadas, pessoas e danos ${ }^{9}$. Não indicou uma subclassificação para estes tipos de seguros, que, no caso do seguro de pessoas, pode abranger o seguro de vida (pessoa em sentido

3 É o caso do direito francês e do direito alemão. Cf. J. C. Moitinho de Almeida, O Contrato de Seguro no Direito Português e Comparado, pg. I9.

4 A respeito, cf. Hans-Peter Scwintowski, Die Rechtsnatur des Versicherungsvertrags, in furistische Zeitung, I4/I996, pg. 702; VÉronique Nicolas, Essai d'une nouvelle analyse du contrato d'assurance, Lgdj, I996, pg. 337; Antonio La Torre, Le Assicurazioni, pg. 3, Giuffrè, 2000.

5 Sobre a categoria dos negócios de garantia, ver Pedro Romano Martinez/Pedro Fuzeta da Ponte, Garantias de Cumprimento, pg, 67 e segs., Almedina, 4ª ed., 2003.

6 Ver, por exemplo, Fábio Konder Comparato, O Seguro de Crédito, pg. I36, RT Editora, i 968 ; Substitutivo ao Capitulo Referente ao Contrato de Seguro no Anteprojeto de Código Civil, in Revista de Direito Mercantil, vol. 5, I972, pg. I47; Seguro de garanti de obrigações contratuais, pg. 35 I, 353, in Novos Ensaios e Pareceres de Direito Empresarial, Forense, Rio de Janeiro, I98 I.

7 Sobre este tema clássico da matéria de seguro, ver Tulio Ascarelli, O conceito unitário do contrato de seguro, in Problemas das Sociedades Anônimas e Direito Comparado, pg. 203 e segs, Saraiva, I969.

8 Sobre o tema ver, por exemplo, Isaac Halperin, Contrato de Seguro, pg. 29 e segs., Buenos Aires, I946.

9 O Decreto-lei 73/66 contempla a seguinte disposição sobre o tema no artigo 30: "Consideramse operações de seguros privados os seguros de coisas, pessoas, bens, responsabilidades, obrigações, direitos e garantias”. 
estrito) e o seguro de pessoas em sentido amplo. Quanto ao seguro de danos, também denominados seguros de interesses, considera o objeto e a classe do interesse segurado. No primeiro caso, pode ter presente um bem determinado (incêndio), um direito determinado (crédito), sobre todo o patrimônio (seguro de responsabilidade civil); quanto à classe, pode abranger o interesse sobre um capital ou sobre um lucro ${ }^{\text {IO }}$.

O artigo 757 precisa, inicialmente, as partes do contrato de seguro. São o segurado e o segurador. O segurador obriga-se a efetuar uma prestação eventual, subordinada à ocorrência de um sinistro. No esforço de tornar o código o centro de referência dos principais aspectos do contrato de seguro, o parágrafo único do artigo 757 sinaliza aspecto disciplinado pela legislação especial (Decreto-lei n. 73/66): não é toda pessoa que pode figurar no contrato como segurador. Somente pessoas jurídicas legalmente autorizadas para este fim podem atuar como seguradoras ${ }^{\mathrm{II}}$. Estas operam dentro do Sistema Nacional de Seguros Privados, instituído no referido Decreto-Lei 73/66, artigo $8^{\circ}$.

No que concerne aos elementos essenciais do contrato de seguro, cumpre apontar primeiramente o risco ${ }^{12}$. Trata-se, com efeito, de elemento nuclear do contrato, na medida em que pelo seguro o risco será assumido pelo segurador, que, na hipótese de sua concretização, deverá efetuar a prestação de garantia a que se obrigou.

Cumpre enfatizar que o risco elevou-se a elemento caracterizador da sociedade contemporânea ${ }^{13}$, marcada pelos traços da globalização e da passagem de uma concepção de modernidade para uma pós-modernidade ${ }^{\mathrm{I}}$. Nesses termos, o contrato de seguro deixa de ser uma conveniência para o particular, alcançando o patamar de necessidade, a fim de resguardar o segurado da concretização de eventos futuros passíveis de afetá-lo de forma substancial no plano econômico - ou mesmo existencial. Nesse contexto, há que se acentuar a finalidade do

io Cf. Halperin, Contrato de Seguro, pg. 30 e segs, op. cit.

I I Nos termos do artigo 24 do Dec.-lei 73, de 2 I. I I. I 966, somente as sociedades anônimas podem ser seguradoras no Direto brasileiro. Nos casos de seguro agrícola e de acidente do trabalho, é possível à seguradora adotar a forma de sociedade cooperativa (parágrafo único do mesmo artigo 24).

I 2 Ver, por exemplo, J. J. Calmon de Passos, O Risco na Sociedade Moderna e seus Reflexos na Teoria da Responsabilidade Civil e na Natureza Furídica do Contrato de Seguro, in I Foro de Direito do Seguro - Anais, pg. I I e segs., Max Limonad, 200 I; François Ewald, Risco, Sociedade e fustiça, in II Foro de Direito do Seguro, pg. 28, Instituto Brasileiro do Direito do Seguro, 2002.

I 3 Cf., por exemplo, Ulrich Beck, Sociedade de Risco: rumo a uma outra modernidade, São Paulo, 20го (no original, Risikogesellschaft, München, I986; Alessandro Argiroffi/Luisa Avitabile, Responsabilità, Rischio, Diritto e Postmoderno - Percorsi di Filosofia e fenomenologia giuridica e morale, pg. Giappicheli, Torino, 2008,

I4 Ver, por exemplo, Francesco Galgano, La globalizacióin en el espejo del derecho, RubinzalCulzoni, 2005; A. Argiroffi/L. Avitable, Responsabilità, Rischio, Diritto e Postmoderno, pg. 53 e segs. 
seguro de propiciar confiança ao contratante ${ }^{\mathrm{I}}$, na medida em que, ao subtrair da posição jurídica do particular o ônus de arcar com a convivência com o risco, insere-o numa situação de maior segurança econômica, e também, existencial.

Em essência, define-se o risco pela possibilidade de um evento econômico desfavorável, um dano, frente os interesses do segurado ou seus beneficiários ${ }^{16}$. A única exigência explicita do Código consiste em que o risco seja predeterminado, ou seja, deve estar explicitada a sua previsão no contrato anteriormente à configuração do prejuízo. Contudo, pode-se mencionar outros requisitos relativamente ao risco: há que se constituir, por exemplo, em situação de realização incerta, bem como em situação lícita, permitida pelo ordenamento e pelos bons costumes. À realização do risco dá-se o nome de sinistro ${ }^{17}$.

Também previsto no texto do artigo 757, o prêmio, por sua vez, é a contraprestação devida pelo contraente do contrato de seguro ao segurador, em decorrência do risco assumido ${ }^{18}$. Cuida-se, igualmente, de elemento essencial do contrato de seguro, que será delineado, no presente trabalho, em item subseqüente.

Cumpre referir o interesse legítimo do segurado como um terceiro elemento do contrato no direito brasileiro. Será este bem jurídico que será garantido pelo segurador no contrato de seguro, que se constitui na relação existente e o segurado ou beneficiário e um determinado bem ou pessoa. O interesse configura requisito de validade do contrato e deverá ser lícito (art. IO4, II, do Código Civil).

Relativamente ao interesse verifica-se o traço unitário do contrato de seguro, na medida em que ele pode abranger tanto um conteúdo econômico determinado, hipótese do seguro de dano, como pode ser livremente arbitrado pela parte, o que ocorre no seguro de pessoas ${ }^{19}$. O artigo 757 exige a legitimação do interesse, o que se configura pela existência de um vínculo econômico ou pessoal para a parte celebrante do contrato de seguro. Esta circunstância é, por exemplo, expressamente afirmada no artigo 790, no caso de seguro sobre vida de outros, ao exigir-se do proponente a declaração de seu interesse pela preservação da vida do segurado - admite-se a presunção do interesse, até prova em contrário, quando o segurado for cônjuge, ascendente ou descendente do proponente (art. 790, parágrafo único).

Sobre o tema, cfr. François Ewald, Risco, Sociedade e Fustiça, in II Fórum de Direito do Seguro, pg. 27, 29.

i6 Cian/Trabucchi, Commentario breve al codice civile, artigo i882 do Código civil italiano, pg. I883, ítem IV, 3a. ed., I 988 , CEDAM.

i 7 Véronique Nicolas, Essai d'une nouvelle analyse du contrat d'assurance, pg. 30, I996, LGDJ, Paris.

i8 Pontes de Miranda, Tratado de Direito Privado, tomo 45, pg. 3 I I $\$ 4.9$ I 9.

i9 Nesse sentido, ver Fábio Konder Comparato, O Seguro de Crédito, pg. 25, op. cit. 
Como afirmado acima, o Código Civil passou a exigir que somente entes legalmente autorizados para a finalidade securitária possam atuar como seguradoras. Cuida-se de preceito que não constava do Código civil de r9i 6. Na doutrina nacional, sustenta-se que a empresarialidade consistiria, portanto, em elemento essencial do contrato de seguro, tendo em vista a referida exigência ${ }^{20}$. Trata-se de percepção que remonta à clássica concepção de Vivante, que vislumbrava o caráter unitário do seguro no elemento técnico da empresa, que atenderia a cálculos de probabilidades, a fim de regular, ou mesmo eliminar, o caráter aleatório do contrato. Contudo, esta orientação não concerne a estrutura interna do contrato e sim, tão-somente, a sua operacionalidade, razão pela qual o caráter empresarial não deve ser reputado como elemento essencial do contrato de seguro ${ }^{21}$. Tanto é assim, que a eventual circunstância de ocorrer a celebração de um contrato de seguro com segurador irregular não conduz à desnaturação do contrato, ou seja, ele não deixará de ser um contrato de seguro para tornar-se um outro tipo de contrato: a sanção incidirá sobre outros planos do negócio jurídico ${ }^{22}$.

Pode-se indagar acerca do destino do contrato de seguro, na hipótese de ele ser celebrado por segurador que não se enquadre nos preceitos legais. $\mathrm{Na}$ doutrina, sustenta-se a orientação da inexistência ${ }^{23}$. Contudo, há que se considerar que o negócio jurídico de seguro existe, independentemente da circunstância de a parte seguradora seguir os preceitos legais. Nesses termos, vislumbra-se que a questão situa-se no plano da validade do negócio jurídico, sendo que em face da incidência do disposto no artigo ı66, inciso V, do Código Civil, há que ser reputado o negócio como nulo, tendo em vista a preterição de solenidade que a lei repute essencial. No caso, reputa-se aqui que a autorização legal para que uma determinada pessoa jurídica possa atuar como seguradora em nosso ordenamento constitui-se em solenidade do contrato de seguro.

De qualquer modo, a sanção de nulidade ao negócio jurídico de seguro não pode resultar em prejuízo ao segurado. Há que incidir nesta situação a proteção da confiança, a fim de resguardar os interesses legítimos do segurado que se vinculou, concretizado no ordenamento brasileiro pelo princípio da boa fé previsto no artigo 422, do Código Civil.

Um outro ponto a ser debatido consiste em saber se, em face da referida previsão, de que somente empresas autorizadas possam atuar como seguradora, admite a constituição de outras modalidades de seguro privado. A questão tem sua origem no direito anterior, pois o artigo I.466, do Código Civil de r9i6,

20 Cf. Ernesto Tzirulnik/Fráviode Queiroz B. Cavalcanti/Ayrton Pimentel, O Contrato de Seguro de acordo com o Novo Código Civil Brasileiro, pg. 39, $2^{\text {a }}$ ed., Revista dos Tribunais, 2003.

2 I A este respeito, ver Ascarelli, Problemas das Sociedades Anônimas, pg. 2 I I, op. cit.; Pontes de Miranda, tomo $45, \$ 4.9$ I I.

22 Nesse sentido, Ascarelli, Problemas das Sociedades Anônimas, pg. 2 I i, op. cit.

23 Cf. Adalberto Pasqualotto, Contratos Nominados iir, pg. 83, op. cit. 
dispunha sobre a possibilidade de um certo número de segurados ajustar entre si o seguro, acerca do risco por todos corrido. Ocorre que este preceito não foi acolhido pela codificação atual. Não se prevê expressamente que possam existir modos associativos, pelos quais as pessoas estabeleçam formas autônomas de cooperação, a fim de prevenir riscos em comum. Ao contrário, ao que se verifica, o código veio ratificar a orientação já existente no Decreto Lei 73-66, no citado artigo 24, sendo que as sociedades cooperativas somente são admitidas a operar os seguros agrícolas, de saúde e de acidentes de trabalho (parágrafo único do artigo 24).

Diante disso, surgiu a indagação sobre esta possibilidade, da preservação em nosso ordenamento do denominado seguro mutualista, ou seguro associativo, pelo qual pessoas se uniriam a fim de contribuir reciprocamente, para obter proteção quanto a determinados riscos, pré-determinados, constituindo, portanto, uma associação. Esta possibilidade foi salvaguardada por setores da doutrina ${ }^{24}$, sendo que se reputou viável a constituição de grupos restritos de ajuda mútua, caracterizados pela autogestão ${ }^{25}$. Cuida-se de temática que encontra concretização na jurisprudência, que trata de problemas decorrentes de associados, associações e dos riscos contratados ${ }^{26}$.

Contudo, não obstante deva ser saudada a posição doutrinária que resguarda a possibilidade de autotutela privada nesta matéria, há que se ponderar que as premissas estabelecidas no posicionamento doutrinário acima indicado, são de difícil concretização na prática. Há que se distinguir, por exemplo, a hipótese de autogestão, de figuras associativas complexas, normalmente órgãos de classe, em que a gestão não é partilhada por todos os membros da pessoa jurídica e sim por apenas um grupo. Da mesma forma, cumpre verificar até que ponto são efetivamente restritos os grupos associativos que passam a desenvolver produtos para a proteção de riscos específicos, para um número indeterminado de pessoas, competindo sem qualquer disciplina frente às empresas devidamente autorizadas no mercado securitário. Acrescente-se que estes grupos associativos podem não estar sujeitos ao Código de defesa do consumidor, caso se entenda que tenham

A respeito, cf. o Enunciado I 85, do CEJ: "A disciplina dos seguros do Código Civil e as normas da previdência privada que impõem a contratação exclusivamente por meio de entidades legalmente autorizadas não impedem a formação de grupos restritos de ajuda mútua, caracterizados pela autogestão.

26 Cf., por exemplo, a seguinte ementa: "Cobrança de seguro de mútuo. Incêndio em estufa de secagem de fumo. Auxílio à reconstrução de estufa. Valor da indenização fixado em assembléia. Pedido de complementação. Improcedente. Efetuando a associação demandada o pagamento da indenização relativa ao auxílio à reconstrução de estufa incendiada, conforme os critérios estabelecidos em assembléia, o autor não tem o direito à cobertura total do prejuízo, devendo obedecer às normas preestabelecidas no regulamento do sistema mutualista da associação. Recurso provido. Unânime”. Recurso Inominado n. 7IO0I 2 I4756, I a Turma Recursal Cível, Jecrs, Rel. João Pedro Cavalli Júnior, j. 30.o8.2007. 
caráter associativo, igualdade entre seus integrantes e não haja pagamento de prêmios, mas sim de quotas entre seus integrantes ${ }^{27}$, pois neste caso não estarão presentes as premissas e fundamentos da tutela do consumidor ${ }^{28}$.

Nesses termos, a difusão irrestrita de seguros privados, com a proliferação de benefícios, como é o caso da proteção veicular, sem a existência de normas regulatórias específicas, pode ensejar extremos prejuízos aos particulares, que por economia, vinculam-se a entes que podem demonstrar ser incapazes de honrar devidamente os interesses protegidos. Há que se concluir, portanto, que a possibilidade de autorização de seguros mutualistas, em nosso ordenamento, há que ser vista de modo restritivo, nos limites do que foi estabelecido pelo Decreto Lei $73 / 66$.

Em relação aos elementos do contrato de seguro, cumpre ainda referir que o Código civil de 2002 não contempla, precipuamente, o mutualismo como elemento da figura. Predomina na concepção do contrato fixada pelo Código atual a estrutura acima delineada, em que o negócio jurídico de seguro será celebrado, de forma bilateral, entre o segurado e a empresa de seguro. Esta orientação depara-se, porém, visão diversa na doutrina ${ }^{29}$, que reputa essencial para a configuração do seguro a existência de uma mutualidade de seguros, vislumbrando no segurador a posição de um intermediário, um gestor da contribuição comum dos segurados ${ }^{3}$.

Há que se considerar, porém, que se a mutualidade não permanece presente de forma inequívoca como elemento legal do contrato de seguro, ela está presente na atividade securitária, na medida em que a reunião de contribuições

27 Neste sentido, Pasqualotto, Contratos Nominados, III, pg. 3 I.

28 A temática de exclusão da tutela do consumidor nas associações também se configura por outros fundamentos, como é o caso da situação em que as associações adquirem os produtos dos associados. Cf. por exemplo a seguinte ementa: "Apelação Cível. Cobrança de seguro de mútuo. Queda de granizo em lavoura de fumo. Pedido de indenização. Descabimento. É inaplicável o CDC no caso porquanto não se trata de relação de consumo. Embora tenha a associação requerida como uma de suas finalidades principais, oferecer segurança contra danos causados por caso fortuito ou força maior no cultivo de fumo, pela prática de mutualismo de indenização, deve obedecer às normas estabelecidas nesse sistema. No caso, adimplido o ressarcimento atendendo-se aos ditames contratuais e o regulamento do sistema mutualista, tem-se que nada mais é devido aos produtores além dos valores pagos. Apelo desprovido”. Ap.

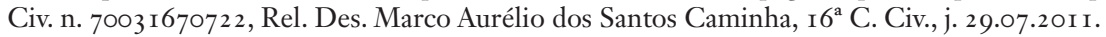

29 Ver, por exemplo, Ovídio Araújo Baptista da Silva, O Seguro como relação jurídica comunitária, in Seguros: uma questão atual, pg. 39 e segs., Max Limonad, 200 I; Véronique Nicolas, Essai d'une nouvelle analyse du contrat d'assurance, pg. I I, I996.

30 Para uma concretização desta orientação na jurisprudência, ao tempo de vigência do Código Civil de ı 16 , ver a seguinte ementa: "Seguro de dano. Perda total. Automóvel. Valor médio. Valor da apólice e valor de ressarcimento. Dominando os negócios de seguro - que não são contratos que se realizem pessoa a pessoa, exigindo uma mutualidade de segurados e intervenção de intermediário - o princípio indenizatório, válida se exibe cláusula que preveja o ressarcimento pelo valor médio de mercado de automóvel, pois o que se há de resguardar é o patrimônio do segurado, nos exatos termos em que resultou desfalcado pela perda do bem. (AP.

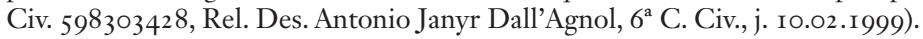


e sua organização por parte da segurança se faz necessária para o seu empreendimento, sendo indispensável a sua preservação ${ }^{3 \mathrm{I}}$. Além disso, reputa-se que a mutualidade se afirma como um princípio do contrato de seguro, tendo em vista a referida importância do fundo de contribuições, decorrente do conjunto de pessoas, para a operacionalidade e para o equilíbrio do negócio jurídico seguro.

Relativamente ao objeto do contrato de seguro, há que se ponderar que não se trata do risco em si, mas está configurado na garantia de tutelar o interesse do segurado, quanto a determinados bens, resguardando- da ocorrência de determinados riscos. Enquadra-se como uma espécie do gênero negócio jurídico de garantia.

\section{B. Reflexões sobre o enquadramento do contrato de seguro}

Quanto ao enquadramento do contrato de seguro, configura-se ele, nos termos da solução legislativa, como contrato bilateral, na medida em que ambas as partes, segurador e segurado, possuem deveres a efetivar: de um lado, o segurado deve pagar o prêmio; de outro, o segurador garante o interesse do segurado contra riscos predeterminados. Tendo em vista a concepção estabelecida pelo código ao seguro, em face da sua percepção de que a relação negocial se estabelece entre o segurado e o segurador, a ênfase deve repousar sobre a bilateralidade do contrato e não sobre uma eventual pluralidade, o que, porém, não deve prima facie excluída, na medida em que, como se referiu, não obstante não faça o código menção à possibilidade de pessoas se congregarem para estabelecer seguros associativos, nada impede que esta prática se configure na vida negocial. A par de

3 I A este respeito, confira o conteúdo da ementa do REsp i 340 Ioo, Rel. Min. Ricardo Villas Bôas Cuevas, $3^{\text {a }}$ Turma, j. 2 I.08.2014). "Recurso Especial. Civil. Seguro de Automóvel. Questionário de avaliação de risco. Informações inverídicas do segurado. Uso e destinação do bem. Interferência no perfil do condutor. Pagamento de prêmio a menor. Má fé. Configuração. Perda do direito à garantia na ocorrência do sinistro. Exegese dos arts. 765 e 766 do CC.

I. O contrato de seguro é baseado no risco, na mutualidade e na boa fé, que constituem seus elementos essenciais. Além disso, nesta espécie de contrato, a boa fé assume maior relevo, pois tanto o risco quanto o mutualismo são dependentes das afirmações das próprias partes contratantes.

2. A seguradora, utilizando-se das informações prestadas pelo segurado, como na cláusula de perfil, chega a um valor de prêmio conforme o risco garantido e a classe tarifária enquadrada, de modo que qualquer risco não previsto no contrato desequilibra econômica o seguro, dado que não foi incluído no cálculo atuarial nem na mutualidade contratual (base econômica do seguro). 3. A má-fé ou a fraude são penalizadas severamente no contrato de seguro. Com efeito, a fraude, cujo princípio é contrário à boa fé, inviabiliza o seguro justamente porque altera a relação de proporcionalidade que deve existir entre o risco e a mutualidade, rompendo, assim, o equilíbrio do contrato, em prejuízo dos demais segurados"

6. Retirar a penalidade da perda da garantia securitária nas fraudes tarifárias (inexatidão ou omissão dolosas em informação que possa influenciar na taxa do prêmio) serviria de estímulo à prática desse comportamento desleal pelo segurado, agravando, de modo sistêmico, ainda mais, o problema em seguros de automóveis, em prejuízo da mutualidade e do grupo de exposição que iria subsidiar esse risco individual por meio do fundo comum”. 
bilateral, o contrato de seguro se caracteriza por ser sinalagmático, isto é, existe correspectividade entre as prestações das partes, no caso o dever do pagamento do prêmio e a garantia assumida pelo segurador ${ }^{32}$.

$\mathrm{O}$ contrato de seguro é de natureza consensual. Perfectibiliza-se com a celebração do vínculo negocial. Não se trata de contrato de natureza real, como, por exemplo o comodato e o depósito, que exigem a entrega da coisa objeto da prestação. Logo, a partir da aceitação pelo segurador surgem deveres para ele ${ }^{33}$, tendo sido estabelecido administrativamente (Circular 251/04), o prazo de 15 dias para a eventual manifestação da seguradora, sob pena de configuração de aceitação tácita da cobertura do risco.

O seguro não se enquadra como contrato solene, pois não se exige forma específica para a sua perfectibilização ${ }^{34}$. O dispositivo do artigo 758 constitui inovação relativamente à solução do Código de I9 I6 (artigo I.433). Neste, exigia-se a redução a escrito do contrato de seguro para que ele obrigasse as partes, sendo que o contrato somente era considerado perfeito quando o segurador remetesse a apólice ao segurado, ou fizesse nos livros o lançamento usual da operação. O Código atual se satisfaz com a apresentação pelo segurado de um documento que comprove o pagamento do prêmio.

Há que se ter presente que o contrato de seguro poderá configurar um negócio de consumo, quando elencar os pressupostos contidos no Código de defesa do consumidor (Lei 8.078/9o), em especial a circunstância de o consumidor configurar-se como destinatário final ${ }^{35}$. Nessa hipótese, serão aplicados ao contrato de seguro disposições específicas da lei de consumo.

O seguro adota em princípio a modalidade de adesão, na medida em que suas cláusulas são normalmente redigidas previa e unilateralmente. Configurando-se a situação de o contrato constituir-se em de consumo e de adesão, considera-se

32 Ver sobre o tema LA Torre, Le Assicurazioni, pg. 7, op. cit.

33 Nesse sentido, cf. REsp n. I 306367 /SP, Rel. Min. Luis Felipe Salomão, 4 a Turma, j. 20.03.20 4.

34 O Código brasileiro se diferencia da solução italiana, que exige expressamente a forma escrita. Cf. o artigo I888, do Código italiano: "Il contratto di assicurazione deve essere provato per iscritto. L'assicuratore è obbligato a rislasciare al contraente la polizza di assicurazione o altro documento da lui sottoscritto".

35 Ver a respeito a seguinte orientação jurisprudencial: "Apelação Cível. Seguros. Plano de Saúde. Inaplicabilidade do código de defesa do consumidor. Reajuste na mensalidade. Faixa etária. Aplicabilidade do Estatuto do idoso. Sinistralidade. Cláusula que estabelece variação somente em favor da operadora. Violação à boa fé. Variação dos custos médico-hospitalres. Planos coletivos. Livre negociação. Repetição simples dos valores pagos a maior. Da inaplicabilidade do Código de defesa do consumidor. I. As regras do Código de defesa do consumidor são inaplicáveis ao caso em exame, porquanto o serviço prestado pela ré aos funcionários da autora constitui insumo da atividade da segunda, que tem como alicerce o capital humano. 2. Destaquese que o artigo serviço prestado pela ré aos funcionários da autora constitui insumo da atividade da segunda para a consecução da finalidade da empresa". Ap. Civ. 7005623 I9I3, Rel. Des. Jorge

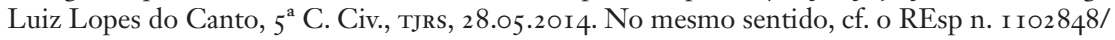
SP, para o acórdão Min. Massami Uyeda, 3 Turma, j. 25.10.20 Io. 
que devam ser aplicam-se as disposições específicas sobre contrato de adesão previstas no artigo 54, do Código de defesa do consumidor (CDC), que estabelece, por exemplo, que os dispositivos do contrato devem ser destacados, não podem ser escritos em caracteres reduzidos e devem ser de conhecimento do consumidor $^{36}$. Mas mesmo que não incidam as previsões do CDC, há disposição no artigo 423 do Código Civil acerca do contrato de adesão, relativamente à possibilidade de interpretação mais favorável ao aderente.

Há especial controvérsia na doutrina contemporânea acerca do caráter aleatório do contrato de seguro, pois sustenta-se a natureza comutativa do contrato ${ }^{37}$, seja pela circunstância, já apontada, de se constituir em uma obrigação de garantia, seja pelo argumento de que a técnica securitária possuiria condições de retirar a álea da contratação.

Contudo, estes argumentos não são suficientes para afastar o caráter aleatório do contrato de seguro ${ }^{38}$, na medida em que a natureza de imponderabilidade acerca do montante da prestação a ser paga pelo segurador permanece em cada contrato, independentemente de a atividade securitária adotar uma atividade industrial. Do mesmo modo, há que diferenciar a referência à aleatoriedade da prestação da circunstância de o segurador assumir uma obrigação de garantia. Trata-se, assim, de esferas distintas no quadro do organismo obrigacional, pois não se deve confundir o dever de prestação - aleatório - com a garantia. Esta, aliás, tem sido a orientação da jurisprudência do Superior Tribunal de Justiça39.

$\mathrm{Na}$ realidade, pode-se distinguir dois planos distintos do quadro contemporâneo do complexo securitário: de um lado, o contrato de seguro, que mantém a natureza jurídica aleatória; de outro, a operação de seguro, ou a organização

36 Trata-se, aliás, de argumento utilizado pela jurisprudência para tutelar o consumidor, afastando a aplicação de cláusulas restritivas de direito no contrato de seguro, em especial as que enquadram determinadas condutas como agravantes do risco. Nesse sentido, ver o REsp I 2 I 9406/MG, Rel. Min. Luis Felipe Salomão, 4 a Turma, j. I 5.02.20 i I.

37 Nesse sentido, ver Ernesto Tzirulnik/Flávio de Queiroz B. Cavalcanti/Ayrton Pimentel, $O$ Contrato de Seguro, pg. 30 e segs., op. cit.

38 A respeito, ver, por exemplo, La Torre, Le Assicurazioni, pg. 8, op. Cit.; Yvonne LambertFaivre, Droit des assurances, pg. I 8 I, Dalloz, 200 I; Véronique Nicolas, Essai d'une nouvelle analyse du contrat d'assurance, pg. 4I e segs., LGDJ, I996; Pasqualotto, Contratos Nominados III, pg. 60, Revista dos Tribunais, 2008; Halperin, Contrato de Seguro, pg. I6, op. cit.

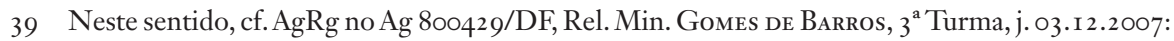
"Agravo Regimental. Seguro. Prêmio. Restituição. Risco. Contrato aleatório. Precedentes. Os valores pagos a título de prêmio pelo seguro por invalidez ou morte não são passíveis de restituição, uma vez que a entidade suportou o risco, como é próprio dos contratos aleatórios". No mesmo sentido, cf. AgRg no REsp I08 I740/MG, Rel. Min. Massami Uyeda, 3 a Turma, j. 23.r I.20IO, cuja ementa é a seguinte: "Agravo Regimental em Recurso Especial. Ação de cobrança. Seguro de Vida. Rescisão contratual. Repetição dos valores pagos a título de prêmio do seguro de vida. Impossibilidade. Precedentes. Agravo Regimental improvido". Ver também EDcl no REsp I $72607 / P R$, Rel. Min. Isabel Galotti, 4 a Turma, j. 2 1.05.2013: 
de sua atividade, que objetiva eliminar, de forma o mais sistemática possível, a imponderabilidade mediante métodos matemáticos e atuariais ${ }^{\circ}$.

Cumpre, referir, ainda, a visão de que o seguro se qualifica como contrato de boa fé4r , ou uberrimae fidei, ou seja contrato em que a noção de boa fé deve estar presente no mais alto grau ${ }^{42}$. A premissa para esta noção decorre da percepção de que o contrato de seguro exigiria, de forma especial, o intercâmbio de informações relativas ao contrato, na medida em que, a partir das referências emanadas pelo segurado, possui o segurador as condições para estabelecer a avaliação dos riscos e a fixação do valor do prêmio 43 . Não obstante seja apontado o caráter recíproco da noção de boa fé, há que se reconhecer, porém, que a exigência de prestação de informações incide preponderantemente sobre o segurado44, o que será destacado em ponto específico do trabalho.

Por fim, há que se pontuar a referência feita na doutrina contemporânea ao caráter social do contrato de seguro 45 , seja por força da incidência, no Código Civil brasileiro, de previsão expressa acerca do princípio da função social nos contratos (art. $42 \mathrm{I}$ ), seja pelas razões anteriormente referidas de que o contrato de seguro exerce uma função institucionalizada como instrumento de segurança e de garantia institucionalizado, seja nas esferas pessoais como negociais, de nossa sociedade, por força do caráter nuclear alcançado pelo risco na sociedade contemporânea ${ }^{46}$.

\section{Temas controvertidos no âmbito dos deveres contratuais}

\section{A. A relativização da mora do segurado no pagamento do prêmio}

Fixados os tópicos essenciais quanto à natureza e os elementos essenciais do contrato de seguro, cumpre destacar questões relativas aos deveres contratuais, que revelam posições da jurisprudência brasileira relativamente ao tema.

O dever precípuo do segurado é o pagamento do prêmio. A este respeito, dedica o Código Civil de 2002 o artigo 763 , determinando que se o segurado

40 Nesse sentido, cf. Yvonne Lambert-Faivre, Droit des assurances, pg. 39, op. cit.

4I Cf. Lambert-Faivre, Droit des assurances, pg. i84, op. cit.

42 Cf. Alberto Monti, Buona fede e Assicurazione, pg. I 25, Giuffrè, 2002.

43 Ver, por exemplo, La Torre, Le Assicurazione, pg. 9, op. cit.; Monti, Buona fede e Assicurazione, pg. I97, op. cit.

44 Cf. Monti, Buona fede e Assicurazione, pg. i 26, op. cit.

45 Ver, por exemplo, Walter Polido, Da Limitação da Autonomia Privada nas Operações de Seguros: coletivização dos interesses - Nova Perspectiva Social e Furídica do Contrato de Seguro, in Revista de Direito do Consumidor, vol. 74, 2010, pg. 74 e segs.

46 Ver, por exemplo, András November/VAlérie November, Risque, assurance et irréversibilité, in Révue européenne des sciences sociales, 2004, pg. I6 I e segs.; W. Heun, Staatliche Risikosteuerung und Verfassung, in $R W 20 \mathrm{I}$, pg. 376 e segs. 
estiver em mora no pagamento do prêmio, ele não terá direito à indenização, se ocorrer o sinistro antes de sua purgação47. Desse modo, caso ele não cumpra com o dever que assumiu, tanto na hipótese de pagamento único ou parcelado, estará sujeito a perder o seu direito correspectivo ao pagamento da indenização pela seguradora.

$\mathrm{O}$ artigo 763 esboça, portanto, uma solução geral para quaisquer hipóteses de inadimplência pelo segurado quanto ao pagamento do prêmio: estabeleceu que o segurado tem o direito a purgar a mora em caso de atraso no pagamento, sendo que a única disposição restritiva consiste no fato de que, se o sinistro ocorrer antes da purgação da mora, o segurado não terá direito ao pagamento da indenização.

Em confronto com o direito comparado, a disciplina do Código Civil é genérica relativamente às possíveis conseqüências sobre o não pagamento do prêmio: no direito italiano, por exemplo, o artigo I9o I, do Código de I 942 prevê detalhadamente diversas situações que podem surgir para o segurado caso ele não pague o prêmio na data aprazada $4^{8}$.

A previsão do Código Civil brasileiro se concentra em um único ponto: a circunstância de incidir em mora não retira do segurado o direito à garantia contratada na hipótese de ocorrer a purgação antes do advento do sinistro. Nesses termos, há que se apontar, desde logo, a ausência de base no texto legal para a solução estabelecida administrativamente pela Circular 302/2005, tendo por objeto o seguro de pessoas, ao determinar o cancelamento do seguro, para os casos de pagamento do prêmio por carnê, na hipótese, de ausência de pagamento da primeira parcela do prêmio pelo segurado. Da mesma forma, a solução de que a falta de pagamento das demais parcelas igualmente poderá determinar o cancelamento do contrato, caso exista previsão nas condições gerais.

Observe-se que a solução concebida pelo Código de 2002 consistiu em estabelecer a suspensão de eficácia do contrato, passível de ser reestabelecida pelo

47 Sobre o tema ver Virgína Duarte Deda de Abreu, O Inadimplemento no pagamento do prêmio no contrato de seguro em face do novo código civil, in $R T$ 824/24.

48 Art. I9or. Mancato pagamento del premio. Se il contraente non paga il premio o la prima rata del premio stabilita dal contratto, l'assicurazione resta sospesa fino alle ore ventiquattro stabilita dal contratto, l'assicurazione resta sospesa fino alle ore ventiquattro del giorno in cui il contraente paga quanto da lui è dovuto. Se alle scadenze convenute il contraente non paga i premi successivi, l'assicurazione resta sospesa dalle ore ventiquattro del quindicesiomo giorno dopo quello dello scadenza. Nelle ipotesi previste daí due commi precedenti il contratto è risoluto di diritto se l'assicuratore, nel termini di sei mesi dal giorno in cui il premio o la rata sono scaduti, non agisce per la riscossione; l'assicuratore há diritto soltanto al pagamento del premio relativo al período di assicurazione in corso e al rimborso delle spese. La presente norma non si applica alle assicurazioni sulla vita". 
segurado mediante o pagamento dos valores em atraso ${ }^{49}$. Não transforma o negócio jurídico de seguro em contrato real5.

A premissa do dispositivo repousa precisamente sobre a existência de mora do segurado relativamente ao pagamento do prêmio. Em princípio, a caracterização da mora decorre das regras gerais dispostas no artigo 397, do Código Civil, configurando-se no caso aqui versado uma situação de mora ex re, pois a obrigação de pagar o prêmio ocorre no dia previsto na apólice, de modo que o seu inadimplemento configura de pleno direito a mora do devedor. Em conseqüência, não haveria a necessidade de notificar o segurado para constituí-lo em mora (dies interpellat pro homine).

Contudo, esta orientação, que se poderia denominar de clássica, quanto à conseqüência do inadimplemento pelo segurado no que concerne ao seu dever contratual, tem sido relativizada pela jurisprudência, tendo em vista a percepção de ser contrária ao princípio da boa fé - e também a função social do seguro -, na medida em que situa o segurado em posição desfavorável, pois este não possuía a percepção de que houve a suspensão da garantia e de que se encontra sujeito à eventual cobrança dos valores devidos ${ }^{5}$.

No âmbito do Superior Tribunal de Justiça, já se fixou a orientação no sentido de que "o atraso no pagamento do prêmio não importa desfazimento instantâneo do seguro, ou suspensão da cobertura securitária, pois é necessária a constituição em mora do contratante pela seguradora" ${ }^{2}$.

Não obstante houvesse sido sustentada a necessidade de medida judicial pela seguradora ${ }^{53}$, para resolver o contrato, prevaleceu no Superior Tribunal de Justiça a posição de ser suficiente a interpelação extrajudicial a fim de caracterizar a mora do segurado, nos termos dos precedentes acima indicados.

Configurado, porém, o requisito da notificação do segurado acerca da inadimplência, e ocorrendo o sinistro no período do inadimplemento, considera-

50 Nesse sentido, cf. José Augusto Delgado, Comentários ao Novo Código Civil, vol. xi, pg. i 7o, ed. Forense, 2004.

5 I Cf. Virgínia Duarte Deda de Abreu, O inadimplemento no pagamento do prêmio no contrato de seguro em face do novo código civil, in $R T$ 824/28.

52 Cf. o REsp 316552-SP, Rel. Min. Aldir Passarinho, Segunda Seção, j. o9. I O.2002, consolidado por decisões posteriores do stJ, como, por exemplo, AgRG no REsp i i i 576/SP, Rel. Min. Maria Isabel Gallotti, 4 ${ }^{\text {a }}$ Turma, j. 25.09.2012, em que na ementa consta o seguinte: “Civil. Recurso Especial. Agravo Regimental. Seguro. Atraso nas prestações. Cancelamento automático ou suspensão do contrato. Impossibilidade. Ausência de notificação. I. Consoante orientação firmada por esta Corte, o simples atraso no pagamento da prestação mensal, sem prévia constituição em mora do segurado, não produz o cancelamento automático ou a imediata suspensão do contrato de seguro firmado entre as partes. 2. Agravo regimental a que se nega provimento".

53 REsp 76.362/MT, Rel. Min. Ruy Rosado de Aguiar, 4a Turma, j. I i. i 2.95. 
se como adequada a posição do segurador que se recusa a pagar a indenização securitária54.

Apenas em situações excepcionais, como na hipótese em que o inadimplemento do segurado perdurou por mais de um ano, configurando uma situação consolidada de inadimplemento, ocorreu a dispensa pelo Superior Tribunal de Justiça do requisito da notificação para a configuração da mora ${ }^{55}$. Trata-se, porém, de caso que não invalida a orientação predominante.

Cumpre, verificar, ainda, qual a extensão do inadimplemento do segurado que configura a mora do segurado. Com base no princípio da boa fé, a doutrina construiu a teoria do adimplemento substancial, com base no qual se evita a resolução do contrato nos casos em que o contrato houver sido cumprido na sua quase integralidade, cujo campo de aplicação originou-se nos contratos de empreitada ${ }^{5}$.

A fim de manter o equilíbrio contratual entre o segurado e o segurador, a jurisprudência nacional tem empregado a teoria do adimplemento substancial nos casos de inadimplemento mínimo do segurado: por exemplo, situações em que apenas uma das parcelas do prêmio deixa de ser paga pelo segurado.

Em face da consolidação deste entendimento no plano jurisprudencial57, cristalizou-se igualmente a orientação na esfera doutrinária, como se verifica do Enunciado 37 I das Jornadas de Direito Civil promovidas pelo Superior Tribunal de Justiça, do seguinte teor: "A mora do segurado, sendo de escassa importância, não autoriza a resolução do contrato, por atentar ao princípio da boa fé objetiva”.

Cumpre destacar que esta construção exige o exame ponderado do caso, a fim de verificar o nível de inadimplemento do segurado. Já decidiu o Superior Tribunal de Justiça que nas hipóteses em que o segurado atrasa o pagamento em mais da metade do prêmio não considera presente o adimplemento substancial, com a conseqüência de ser possível a liberação da seguradora $5^{8}$.

54 Ver, por exemplo, REsp 964826/RS, Rel. Min. Luis Felipe Salomão, 4 a Turma, j. 20.03.20I2, em cuja ementa consta o seguinte: “...2. As instâncias ordinárias reconheceram que o segurado foi previamente notificado em vida acerca da mora e das conseqüências desta para a cobertura securitária, ocorrendo o sinistro durante o período de inadimplência, circunstância que torna lícita a negativa da seguradora em relação ao pagamento da indenização securitária. 3 . Recurso especial não conhecido".

55 REsp 842.408/RS, Rel. Min. Humberto Gomes de Barros, $3^{\text {a }}$ Turma, j. i6.i i.2006.

56 Cf. Clóvis do Couto e Silva, O princípio da boa fé no Direito Brasileiro e Português, in O Direito Privado na visão de Clóvis do Couto e Silva, pg. 33, 55, Livraria do Advogado, 1997.

57 Ver por exemplo a Ap. Civ. n. 70001605252 , da $5^{\text {a }}$ C. Civ. do tjrs, Rel. Des. Sergio Pilla DA Silva, j. 09.I I.2000, em cuja ementa consta o seguinte: "Seguro. Falta de pagamento de duas prestações pelo segurado. Irrelevância. Cobertura devida no mesmo percentual do prêmio pago. Mesmo que o segurado não tenha pago as duas últimas prestações é devida a cobertura de sinistro, já que ocorreu adimplemento substancial".

$5^{8}$ Nesse sentido, ver REsp 41 5.97 I/SP, Rel. Min. Nancy Andrighi, $3^{a}$ Turma, j. I4.05.2002. 
Há que se ter presente que a circunstância de o segurado sofrer a perda do direito à indenização por força do inadimplemento do prêmio, não implicará a eventual liberação do pagamento dos valores atrasados. A premissa, porém, para que a seguradora possa exigir os valores devidos decorre da referida notificação, ato pelo qual terá o segurado plena ciência das conseqüências do inadimplemento relativamente à referida perda da indenização e quanto à possibilidade de cobrança do valor do prêmio em atraso.

\section{B. O dever do segurado de abster-se quanto ao agravamento dos riscos e sua conseqüência para o contrato de seguro}

O negócio jurídico de seguro deve manter uma correlação entre o prêmio e o risco contratados. Nesses termos, se houver um aumento da probabilidade de ocorrência do risco, esta circunstância pode afetar, de modo sensível, o referido equilíbrio contratual.

Cabe, portanto, ao segurado abster-se de condutas que agravem o risco. Cuida-se de um 'não fazer' que é imposto à parte, a fim de preservar a base negocial do contrato de seguro, evitando a alteração das circunstâncias. Desse modo, dispõe o artigo 768, do Código Civil de 2002, que o segurado perderá o direito à garantia se agravar intencionalmente o risco objeto do contrato.

Há que se ter presente, porém, que o comportamento do segurado deve preencher determinados requisitos, a fim de bem caracterizar a situação prevista na lei, pois não é qualquer conduta sua que pode ser caracterizada como fator ampliativo do risco.

Um primeiro pressuposto consiste na intencionalidade da conduta do segurado: o agravamento do risco decorrente de sua iniciativa deverá ser voluntário. Deve-se verificar, portanto, a conduta do segurado, a fim de observar se houve por parte dele o propósito consciente de elevar o risco.

Um segundo requisito consiste na efetiva contribuição do ato do segurado para ampliar o risco, o que exigirá uma comprovação técnica. Em essência, faz-se mister uma análise da causalidade entre o ato praticado pelo segurado e os fatores determinantes do sinistro. Do contrário, não se configura a previsão legal.

No Direito brasileiro, não se contempla uma definição do que se efetivamente considera como conduta ampliativa do risco. Não há a menção à culpa grave ou dolo, presentes no artigo I90o, do Código Civil italiano de 1942. Não se contempla, por outro lado, o parâmetro referido no artigo r. 898 do mesmo Código, que reputa "como situação de agravamento de risco aquela que, se houvesse existido ou fosse conhecida do segurador quando da conclusão do contrato, ele não teria consentido no seguro ou o teria feito mediante um prêmio mais elevado" 59 .

59 "Il contraente há l'obligo di dare immediato avviso all'assicuratore dei mutamenti che aggravano il rischio in modo tale che, se il nuovo stato di cose fosse esistito e fosse stato conosciuto 
Exemplo ilustrativo acerca desta temática encontra-se no caso de transferência de veículo pelo segurado, sem que exista a comunicação à seguradora. Sobre este tópico o Superior Tribunal de Justiça foi reiteradamente decidindo que não se considera agravamento do risco a simples transferência de titularidade do veículo de uma pessoa à outra sem comunicação à seguradora ${ }^{60}$. Esta orientação foi consolidada na Súmula 465: "Ressalvada a hipótese de efetivo agravamento do risco, a seguradora não se exime do dever de indenizar em razão da transferência do veículo sem a sua prévia comunicação".

O Superior Tribunal de Justiça tem estabelecido, igualmente, que a omissão do segurado quanto ao fato de não possuir carteira de habilitação, e possuir idade avançada, não guarda relação lógica com o roubo do veículo, razão pela qual não se justifica a perda da garantia ${ }^{61}$. A mesma orientação encontra-se, por exemplo, diante de conduta do segurado que conduziu com carteira de motorista suspensa e em alta velocidade, tendo sido estabelecido que não se verificou que este comportamento teria sido a causa do sinistro ${ }^{62}$.

Da mesma forma, não enquadrou o Superior Tribunal de Justiça como conduta agravadora de risco o ato do segurado que subiu em torre metálica elevada, sob o fundamento de que este comportamento se caracteriza como uma conduta razoável e previsível na vida das pessoas ${ }^{63}$.

dall'assicuratore al momento della conclusione del contratto, l'assicuratore non avrebbe consentito l'assicurazione o l'avrebbe consentita per um premio più elevato".

60 REsp n. i88.694-MG, 4 a Turma, Rel. Min. Cesar Asfor Rocha, j. r 8.04.2000, cuja ementa é a seguinte: "Seguro facultativo. Transferência de veículo. Ausência de comunicação à seguradora. A só e só transferência do veículo segurado sem comunicação à seguradora não constitui agravamento do risco. Na hipótese, como retratado pela decisão recorrida, não houve má-fé por parte do anterior e do atual proprietários do veículo no que seja atinente à sua transferência, não tendo havido, objetivamente, ofensa aos termos do contrato, pois ausente qualquer comprovação de que a transferência se fizera para uma pessoa inabilitada, seja técnica ou moralmente".

6i Cf. REsp i.2 10.205-RS, Rel. Min. Luis Felipe Salomão, $4^{a}$ Turma, j. I ${ }^{\circ}$.09.20 i i. Na ementa, consta o seguinte: "No caso concreto, a circunstância de a segurada não possuir carteira de habilitação ou de ter idade avançada - ao contrário do seu neto, o verdadeiro condutor - não poderia mesmo, por si, justificar a negativa do segurador. É sabido, por exemplo, que o valor do prêmio de seguro de veículo automotor é mais elevado na primeira faixa etária (I 8 a 24 anos), mas volta a crescer para contratantes de idade avançada. Por outro lado, o roubo do veículo segurado - que, no caso, ocorreu com o neto da segurada no interior do automóvel - não guarda relação lógica com o fato de o condutor ter ou não carteira de habilitação. Ou seja, não ter carteira de habilitação ordinariamente não agrava o risco de roubo de veículo. Ademais, no caso de roubo, a experiência demonstra que, ao invés de reduzi-lo, a idade avançada do condutor pode até agravar o risco de sinistro - o que ocorreria se a condutora fosse a segurada, de mais de 70 anos de idade - porque haveria, em tese, uma vítima mais frágil a investidas criminosas".

62 Cf. RESp i i 75577/PR, Rel. Min. Nancy Andrighi, j. i8.i i.20io.

63 Cf. REsp 795027/RS, 4 Turma, Rel. Min. Aldir Passarinho JR., j. I8.03.20 io, em que consta o seguinte: "Não consubstancia situação de agravamento de risco o ato do segurado que sobe em torre metálica elevada, mas de fácil acesso, para descortinar vista panorâmica, porquanto constitui comportamento aventureiro razoável e previsível na vida das pessoas, como também acontece com escalada de árvores, pedras, trilhas íngremes, e coisas semelhantes". 
Observa-se destas situações, objeto de análise da jurisprudência da Corte Especial, que o segurado não é obrigado a viver em uma espécie de redoma, a fim de evitar quaisquer condutas passíveis de serem reputadas como agravantes do risco. Não se poderá, por exemplo, exigir que ele estacione seu automóvel sempre em estacionamento, a fim de prevenir a possibilidade de um furto de seu veículo. Da mesma forma, não se poderá pretender que o segurado retire todos os seus pertences do veículo, e os carregue pela via pública, a fim de prevenir a hipótese de furto de bens eventualmente segurados. Em uma sociedade que se caracteriza como sendo de risco, não se pode, em essência, pretender que o segurado viva em estado de prevenção, de reclusão, a fim de manter o objeto do contrato de seguro.

Contudo, uma situação contemporânea, que gera extrema discussão como fator de agravamento de risco, consiste na embriaguez do segurado, que se envolve em acidente. Esta matéria, porém, no âmbito do Superior Tribunal de Justiça, tem sido reiteradamente afastada como causa de agravamento do risco, sob o fundamento de não se configurar automaticamente em razão da embriaguez do segurado, impondo-se à seguradora o ônus de provar que ela contribuiu decisivamente para o sinistro ${ }^{64}$.

Esta orientação tem prevalecido mesmo nos casos em que se constata a dosagem ilícita no sangue do segurado, em patamar superior ao permitido em lei, sob o fundamento de ser necessária a comprovação da relação de causalidade entre a embriaguez e o acidente ${ }^{6}$. A mesma solução é dada pelo Superior Tribunal de Justiça nos casos em que no acidente envolve-se o filho do condutor e nele se

64 Ver, por exemplo, o REsp 780757/SP, 4 a Turma, Rel. Min. João Otávio de Noronha, cuja ementa consta o seguinte: "I. A simples relação entre o estado de embriaguez e a queda fatal, como única forma razoável de explicar o evento, não se mostra, por si só, suficiente para elidir a responsabilidade da seguradora, com a conseqüente exoneração de pagamento da indenização prevista no contrato. 2. A legitimidade de recusa ao pagamento do seguro requer a comprovação de que houve voluntário e consciente agravamento do risco por parte do segurado, revestindose seu ato condição determinante na configuração do sinistro, para efeito de dar ensejo à perda da cobertura securitária, porquanto não basta a presença de ajuste contratual prevendo que a embriaguez exclui a cobertura do seguro. 3. Destinando-se o seguro a cobrir os danos advindos de possíveis acidentes, geralmente oriundos de atos dos próprios segurados, nos seus normais e corriqueiros afazeres do dia-a-dia, a prova do teor alcoólico na concentração de sangue não se mostra suficiente para se situar como nexo de causalidade com o dano sofrido, notadamente por não exercer influência o álcool com idêntico grau de intensidade nos indivíduos. 4. A culpa do segurado, para efeito de caracterizar desrespeito ao contrato, com prevalecimento da cláusula liberatória da obrigação de indenizar prevista na apólice, exige a plena demonstração de intencional conduta do segurado para agravar o risco objeto do contrato, devendo o juiz, na aplicação do art. I.454 do Código Civil de ı i 6, observar critérios de equidade, atentandose para as reais circunstâncias que envolvem o contrato (art. I.456 do mesmo diploma)." No mesmo sentido, cf. AgRg no REsp I 297 I 87/RS, Min. Ricardo Villas Bôas Cueva, 3 a Turma, j. I 5.02.2OI3.

65 AgRg no Ag r322903/RS, Rel. Min. Raul Araújo, 4a Turma, j. or.03.20 i i; AgRG no REsp I 279854 SP, Rel. Min. Massami Uyeda, 3 a Turma, j. I6.02.20 2. 
verifica a embriaguez, sob o fundamento de não se tratar, no caso, de situação propiciada pelo segurado diretamente ${ }^{66}$.

A fim de tutelar o segurado, a Corte Especial recorre, ainda, ao argumento de que as cláusulas limitativas de direito - como é o caso da que nega cobertura em função da embriaguez -, exigem o conhecimento do segurado, nos termos do art. 46 e $54, \$ 4^{\circ}$, do Código de Defesa do Consumidor. Não se tendo configurado esta circunstância ${ }^{67}$, tem direito o segurado à indenização ${ }^{68}$.

Consoante se referiu acima, a sanção prevista em lei consiste na perda do direito à garantia, com a conseqüente liberação do segurador de seu dever de pagamento do valor devido. Não haverá dever para o segurador de devolver o prêmio recebido.

\section{A extensão do dever de informar do segurado}

\section{I. $O$ dever de informar do segurado quanto a riscos preexistentes}

A questão do dever de informar no contrato de seguro está disposta, de forma geral, no artigo 765 do Código Civil ${ }^{69}$. Este dispositivo reproduz, em essência, o teor do artigo I.443, do Código Civil de i9 I6. Explicita, porém, o seu conteúdo, ao afirmar que a observância da boa fé pelo segurador e pelo segurado devem ocorrer tanto no momento da celebração quanto durante o curso do contrato. $\mathrm{Na}$ realidade, ainda esta referência permanece ilustrativa, pois o princípio da boa fé incide ainda nas fases das tratativas - período pré-contratual - e se estende após a conclusão do contrato (post pactum finitum).

Com a adoção deste preceito, expressa-se a importância do princípio da boa fé para o contrato de seguro, decorrente da relevância dos deveres - como o de informação - a serem atendidos pelas partes na sua relação contratual $7^{\circ}$. Precisamente por este fundamento que se considera o contrato de seguro como o vínculo de boa fé por excelência, como anteriormente ressaltado.

66 Cf., por exemplo, AgRg no REsp i I73 I39/SP, $3^{\text {a }}$ Turma, Rel. Min. Massami Uyeda, j. $03.05 .201 \mathrm{I}$.

67 Cf. REsp i 2 I9406/MG, 4 a Turma, Rel. Min. Luis Felipe Salomão, j. I 5.02.20 i I.

68 Cf. AgRG no REsp r $279854 / \mathrm{SP}, 3^{\text {a }}$ Turma, Rel. Min. Massami Uyeda, j. i 6.02.201 2 ; cf. também AgRG no REsp i $297187 / \mathrm{RS}, 3^{\mathrm{a}}$ Turma, Rel. Min. Ricardo Villas Bôas Cueva, j. 05.02 .2013 .

69 Art. 765. "O segurado e o segurador são obrigados a guardar na conclusão e na execução do contrato, a mais estrita boa fé e veracidade, tanto a respeito do objeto como das circunstâncias e declarações a ele concernentes".

70 Cumpre explicitar que, no Código civil de 2002 a boa fé encontra-se regulada como princípio geral dos contratos no artigo 422. Além disso, no Código de Defesa do Consumidor, de i99o, está contemplada igualmente a boa fé como diretriz fundamental da política de defesa do consumidor e como parâmetro para a apuração da abusividade de cláusulas contratuais (artigos $4^{\circ}$ e $5 \mathrm{I}$, inciso IV). 
O fundamento para a determinação do dever de informar decorre da própria estrutura do contrato de seguro: ele visa à garantia contra um risco, que decorre de dados preexistentes das próprias partes. Para que o vínculo possua um equilíbrio, cumpre então que se atente à realidade do que se declara no contrato.

A preocupação do legislador neste sentido se expressa em dois momentos: de um lado, sublinha que as partes devem guardar a mais 'estrita boa fé', o que denota a intenção do legislador de destacar a necessidade de as partes atenderem o dever de lealdade e correção. De outro, especifica o dever de boa fé ao agregar a necessidade de as partes atentarem para a veracidade de suas declarações. Ou seja, não deve haver qualquer tipo de discordância entre a manifestação de vontade das partes relativamente ao objeto do contrato e fatos ou circunstâncias a ele relacionadas.

Inexiste, porém, sanção específica para o descumprimento do preceito. A solução deve ser a de que se houve descumprimento do princípio da boa fé, será afetado o plano da eficácia dos negócios jurídicos, especificamente do contrato de seguro, com a conseqüência de que a parte afetada pelo desatendimento do princípio estará desobrigada da sua prestação co-respectiva. Esta solução será concretizada em artigos específicos (766).

Um outro ponto importante relativamente ao dever de informar consiste em que, no contrato de seguro, o segurador é dependente das informações prestadas pelo segurado para auferir efetivamente as condições relativas ao risco, a fim de apurar a correlação com o prêmio estipulado.

Logo, esta conduta do segurado deve ser permeada pela boa fé - nos termos do art. 765. Nesses termos, regula o código dois deveres para o segurado ou o seu representante: deverá pautar sua conduta pela veracidade, prestando declarações correspondentes à realidade; não poderá, por outro lado, omitir, deixar de informar acerca de dados relativos ao interesse segurado. Trata-se de solução que encontra base no artigo I.444, do Código Civil de i9r6.

Cumpre, portanto, que o segurado informe a integralidade das circunstâncias passíveis de influenciar o contrato de seguro: de forma específica menciona o código dois pontos específicos: a proposta e a taxa do prêmio. Ou seja, se houvesse ciência do segurador acerca do conjunto dos fatos concernentes ao interesse objeto do contrato de seguro poderia não haver contratação ou então teria sido outro o valor pactuado como prêmio estipulado.

A sanção prevista pelo legislador para o segurado consiste na perda da garantia contratada agregada da permanência do dever de pagamento do prêmio (art. 766). Esta penalidade, porém, exige que se demonstre que a ausência, ou incompletude, de informação decorre de má fé do segurado.

Caso não se verifique este pressuposto, e havendo insuficiência de informação, prevê o parágrafo único do artigo 766 que surgirá para o segurador uma dupla faculdade: de um lado, o direito à resolução do contrato; de outro, o direito a cobrar a eventual diferença do prêmio, mesmo após a configuração do sinistro. 
Observa-se que o preceito estabelece uma relevância para as informações omitidas: devem ser essenciais para o consenso acerca do contrato de seguro ou no valor da remuneração. Desse modo, extrai-se do texto legal que não é qualquer omissão ou inexatidão que poderá acarretar a sanção prevista. Faz-se mister existir uma relação lógico-causal entre as circunstâncias omitidas e objeto do contrato. Deve ser feita uma ponderação para que se analise o equilíbrio contratual no caso concreto e se ele é efetivamente afetado pela omissão ou pela falsidade das informações ${ }^{7 \mathrm{I}}$.

Esta orientação encontra-se presente na jurisprudência ainda antes da vigência do atual Código civil, na medida em que se examina de forma criteriosa se a eventual ausência de informação envolve circunstância capaz de efetivamente aumentar o risco ${ }^{72}$. Não se considera presente a relação lógico causal entre a omissão das informações e o contrato de seguro, quando, por exemplo, se reputa existente doença preexistente do segurado, não informada ao segurador, mas se verifica que o segurado possui longo estado de saúde regular após a contratação, tendo contribuído durante largo período mediante o pagamento do prêmio do contrato de seguro, que foi constantemente renovado 73 .

Acresce que se impõe ao segurador o ônus de demonstrar a eventual má fé do segurado na incompletude das informações prestadas pelo segurado. $\mathrm{Na}$ praxe securitária, são apresentados ao segurado formulários, com uma série de questionamentos, como $\mathrm{O}$ de avaliação de risco, para que ele informe detalhadamente todos os elementos relativos ao interesse segurado. Podem ser exigidos, igualmente, exames do segurado para atestar o seu estado de saúde.

$\mathrm{Na}$ jurisprudência, encontra-se disseminada a orientação que se o segurador não exige a realização de exames médicos prévios à contratação do seguro, aceita a contratação e aufere os prêmios pagos pelo segurado, não pode posteriormente

7 I Sobre este ponto, ver o Enunciado 374, da Iv Jornada de Direito Civil do STJ, com o seguinte teor: "no contrato de seguro, o juiz deve proceder com equilíbrio, atentando às circunstâncias reais, e não a probabilidades infundadas, quanto à agravação dos riscos.

72 Ver por exemplo o REsp n. I88.694-MG, Rel. Min. Cesar Asfor Rocha, 4 a Turma, j. I 8.04.2000, em cuja ementa consta: "A só e só transferência de titularidade do veículo segurado sem comunicação à seguradora não constitui agravamento do risco. Na hipótese, como retratado pela decisão recorrida, não houve má-fé por parte do anterior e do atual proprietários, do véiculo no que seja atinente à sua transferênia, não tendo havido, objetivamente, ofensa aos termos do contrato, pois ausente qualquer comprovação de que a transferência se fizera para uma pessoa inabilitada, seja técnica ou moralmente".

73 Nesse sentido, ver AgRg no REsp n. 9i3.r 20-SP, Rel. Min. Sidnei Beneti, $3^{\text {a }}$ Turma, j. 05.08.20I0, em cuja ementa consta o seguinte: "I - Excepcionalmente, a omissão do segurado não é relevante quando contrata seguro e mantém vida regular por vários anos, demonstrando que possuía, ainda, razoável estado de saúde quando da contratação da apólice. II - Aufere vantagem manifestamente exagerada, de forma abusiva e em contrariedade à boa fé objetiva, o segurador que, após mais de duas décadas recebendo os prêmios devidos pelo segurado, nega cobertura, sob a alegação de que se trata de doença pré-existente. III - Agravo Regimental improvimnto". 
pretender eximir-se do pagamento do valor contratado ${ }^{74}$. A exigência de exames por parte da seguradora seria a forma pela qual o segurador poderia atentar para o ônus da prova que lhe cabia, nos termos da legislação processual75.

Observe-se, aqui, que esta concepção constitui uma demonstração de alteração da concepção adotada pelo legislador, que centra a boa fé numa conduta autônoma da pessoa. Para a jurisprudência, a boa fé passa a ter um caráter subjetivo, tendo que ser caracterizado pela seguradora que houve a conduta imprópria da parte.

\section{2. $O$ dever de informar do segurado quanto à agravação dos riscos}

A par desta primeira gama de questões relativas às informações pessoais, presentes no momento no momento da celebração do contrato, o Código de 2002 impõe outra esfera de deveres de forma expressa ao segurado no artigo 769: informar a outra parte, acerca de qualquer circunstância capaz de aumentar, de modo significativo, o risco objeto do contrato.

Cuida-se, em essência, de nova concretização do princípio de boa fé, que emoldura o contrato de seguro, impondo as partes diversos deveres durante o desenvolvimento do vínculo negocial.

$\mathrm{Na}$ doutrina nacional, extrai-se do texto legal (art. 769) uma hipótese de regulação para a onerosidade excessiva do contrato de seguro, cuja regra geral encontra-se nos artigos 478 a 480, do Código Civil ${ }^{6}$. A finalidade da regra é de resguardar o equilíbrio econômico do contrato, em face da modificação ocorrida na base de cálculo de referência do prêmio estipulado, não obstante o caráter aleatório do negócio jurídico de seguro.

No direito italiano, há quem, porém, vislumbre na solução legislativa a preocupação em conservar a necessária correspondência objetiva entre risco e prêmio, fundamento indispensável do contrato de seguro 77 . Contudo, essa visão decorre do fato de o Código Civil italiano expressamente excluir a aplicação das

74 Ver por exemplo AgRG no Agravo em REsp n. I49.893-SP, Rel. Min. Marco Buzzi, 4 a Turma, j. I8. I0.20 I 2; AgRG no AgRG no AREsp I4.594/SP, Rel. Min. Luis Felipe Salomão, $4^{a}$ Turma, j. 07.02.2012; EDcl no Ag. I.I62.957/DF, Rel. Min. Paulo de Tarso Sanseverino, $3^{\text {a }}$ Turma, j. I 7.05.20II.

75 Ver, por exemplo, a Ap. Civ. 7005 I 786283 , da 5 a C. Civ. do tJrs, Rel. Des. Jorge Luiz Lopes do CANTo, j. 28. i I.2002, em cuja ementa consta o seguinte: "No caso em tela a seguradora não logrou êxito em comprovar o agravamento do risco contratado em razão de dolo ou má fé da parte segurada, ônus que lhe cabia e do qual não se desincumbiu, a teor do que estabelece $o$ art. 333, inciso II, do Código de Processo Civil. Ademais a demandada sequer exigiu exames para respaldar as informações de saúde que foram prestadas pela estipulante no cartão-proposta. Dessa forma, não se mostra razoável tentar se eximir da responsabilidade decorrente de contrato do qual percebeu o prêmio, sem qualquer objeção às declarações apresentadas".

76 Ver, por exemplo, Adalberto Pasqualotto, Contratos Nominados iII, pg. I I 9, op. cit.; Nelson Borges, A Teoria da Imprevisão e os Contratos Aleatórios, in $R T$ 782/, pg. 78 e segs.

77 Sobre o tema, cfr. La Torre, Le Assicurazioni, pg. 96, op. cit. 
regras sobre onerosidade excessiva ao contrato aleatório (art. I469) $7^{8}$. Ora, não obstante ter o Código Civil de 2002 adotado a teoria da onerosidade excessiva doutrina de matriz italiana -, não contém a nossa legislação o mesmo dispositivo restritivo, o que conduz à conclusão de inexistência de contradição legislativa em nosso sistema. Trata-se de solução que encontra paralelo na doutrina portuguesa, que sustenta a possibilidade de aplicação da teoria da onerosidade excessiva aos contratos aleatórios 79 .

Contém o dispositivo um primeiro requisito de ordem temporal a ser atendido pelo segurado: este deve informar o segurador 'logo que saiba', ou seja, no menor espaço de tempo possível, a partir do momento em que tiver ciência do ocorrido. Serão as circunstâncias do caso a determinar se o segurado efetivamente atendeu a este requisito, pois ele poderá alegar dificuldade ou impossibilidade de ciência imediata da situação e a conseqüente comunicação ao segurador. $\mathrm{O}$ critério da ponderação atua nesta questão, a fim de verificar se o segurado efetivamente informou em um período razoável de tempo. Observe-se que inexiste forma expressa para a comunicação por parte do segurado, o que implica presumir que, em princípio, poderia ser feito mesmo oralmente e provado até mesmo por testemunhas.

O dever de informar não incide, porém, quaisquer hipóteses. Em primeiro lugar, trata-se de circunstâncias não vinculadas ao segurado, alheios à sua vontade, pois estes estão abrangidas pelo preceito precedente (art. 768), bem como a expressão "logo que saiba" depreende que se trata de incidentes externos ao segurado.

Em segundo lugar, circunscreve-se, apenas, a fatos efetivamente aptos a elevar o risco de forma efetiva. Observa-se, na redação do artigo 769 , evolução em relação à terminologia do artigo I.455 do código anterior: este exigia a comunicação de qualquer incidente, que de qualquer modo, pudesse agravar o risco. A regra atual restringiu, portanto, o dever do segurado, pois não somente exige uma relevância - a agravação deve ser substancial -, como também requer um patamar de causalidade, na medida em que o incidente deverá ser capaz de determinar o agravamento do risco coberto.

Cumpre referir, ainda, que o incidente passível de agravar o risco deve ser novo, posterior à estipulação, não tendo sido previsto no momento da celebração do contrato de seguro. Afinal, a solução legal pressupõe que o risco já existia e agravou-se, de sorte que se há de presumir pela sua contestação anterior e o que surge é tão-somente uma questão quantitativa ${ }^{80}$.

78 "Art. I469 - Le norme degli articoli precedenti non si applicano ai contratti aleatori per loro natura (I872, I919, I933) o per volontà delle parti (I448, I672, I472)”.

79 Ver, por exemplo, Mario Júlio de Almeida Costa, Direito das Obrigações, pg. 283, $6{ }^{\mathrm{a}}$ Ed. Almedina.

80 Nesse sentido, cf. La Torre, Le Assicurazioni, pg. 99, op. cit. 
Há que se destacar o ponto de que não são quaisquer circunstâncias que podem ser reputadas como agravantes do risco. Eventos naturais, por exemplo, ligados ao desenvolvimento do bem, tais como a eventual valorização da coisa segurada no curso do tempo, não podem ser empregadas como argumento pelo segurador para caracterizar a previsão legal. Da mesma forma, cumpre verificar se o incidente possui uma certa permanência no tempo, se é, em suma duradouro, pois, em princípio, um fato transitório não deve ser reputado suficiente para caracterizar a hipótese legal ${ }^{8 \mathrm{I}}$.

Está prevista a sanção de perda da garantia para o segurado, na hipótese de violação no seu dever de informação, caso se comprovar que a sua omissão decorre de má-fé, o que se constitui em ônus do segurador.

Ciente da circunstância relatada pelo segurado, possui o segurador o prazo de quinze dias para avaliar a efetiva repercussão do agravamento do risco sobre o equilíbrio do contrato, a fim de decidir-se pela resolução contratual. Ocorrerá a extinção do contrato. Cuida-se, aqui, de direito potestativo do segurador, pois, nos termos da lei, o segurado não pode se opor à decisão do segurador. $\mathrm{O}$ único requisito é a notificação por escrito ao segurado.

Não obstante não exista previsão expressa no artigo 769, há que se deduzir da redação legislativa que se ocorrer o sinistro após a comunicação pelo segurado e antes da resilição pelo segurador, estará vinculado o segurador no pagamento da soma devida ao segurado. Não contempla o nosso ordenamento disposição equivalente à parte final do citado artigo i 898, do Código Civil italiano, que regulou tanto a possibilidade de exclusão do segurador, caso em caso de agravamento substancial do risco, que teria conduzido à não celebração do contrato, como ao eventual pagamento proporcional da indenização, em consideração à nova relação entre prêmio e risco agravado ${ }^{82}$.

Na redação dada pelo Código brasileiro, o segurador não se desvincula imediatamente: continua obrigado pelo período de trinta dias após a notificação, de sorte que, se o sinistro ocorrer neste período de tempo, subsiste a garantia securitária.

Por outro lado, cumpre ao segurador restituir ao segurado, em face da notificação, a diferença do prêmio recebido, em decorrência da menor duração do contrato, por força de sua decisão de resilir o contrato.

Deve-se entender ser ônus do segurador demonstrar a incidência dos pressupostos legais, a fim de pleitear a extinção do contrato. No caso, consoante

8 I Cf. La Torre, Le Assicurazioni, pg. 99, op. cit.

82 "Art. I898. Se il sinistro si verifica prima che siano trascorsi i termini per la comunicazione e per l'efficacia del recesso, l'assicuratore non risponde qualora l'aggravamento del rischio sia tale che egli non avrebbe consentito l'assicurazione se il nuovo stato di cose fosse esibito al momento del contratto; altrimenti, la somma dovuta è ridotta, tenuto conto del rapporto tra il premio stabilito nel contratto e quello che sarebbe stato fissato se il maggiore rischio fosse esibito al tempo del contratto stesso". 
se afirmou, não somente deverá demonstrar o agravamento fundamentado do risco, como também que havia o conhecimento pelo segurado.

Na praxe securitária pode ocorrer que conste do contrato disposição prevendo situações capazes de agravar o risco e que devem ser comunicadas pelo segurado. Nada impede que o contrato regule que, na hipótese de agravamento do risco, seja facultado às partes modificar o contrato, a fim de evitar a sua extinção.

A disciplina brasileira vinculou-se à regra italiana, do artigo ı.898, do Código de 1942, que não previu esta solução, o que indica um modelo contratualístico que pode ser pouco operacional, em que a lógica legislativa aponta para o fim do contrato e não para a sua preservação. Observe-se que o direito francês, por exemplo, no art. Li i 3-4, do Código de Seguros (Code des Assurances) prevê expressamente a possibilidade de o segurador - a par da resilição - propor ao segurado um novo valor de prêmio no caso de agravamento de risco. Cabe ao segurador informar ao segurado que na hipótese de não aceitação do novo valor proposto, a conseqüência será a resilição contratual ${ }^{83}$.

\section{Questões controvertidas quanto ao cumprimento pelo segurador de seu dever de garantia}

\section{A. O pagamento pelo segurador}

Quanto ao adimplemento do seguro, cumpre, primeiramente, estabelecer que o ordenamento brasileiro se preocupa com o modo como será cumprido o dever de garantia assumido pelo segurador (artigo 776). Em princípio, o implemento do seu dever implica no pagamento em dinheiro ao segurado por força do prejuízo, surgindo a denominada reposição in natura apenas na hipótese em que houver cláusula contratual dispondo nesse sentido. Busca-se impedir tentativas de efetuar o cumprimento por outros meios liberatórios: ou seja, está assegurado que o adimplemento deverá ocorrer em dinheiro.

A norma faz menção à existência de prejuízo, o que induz, normalmente, aos casos de seguros de danos em que está presente a situação de um sinistro com o perecimento do bem segurado. Contudo, é forçoso ter presente que várias hi-

83 No original: En cas d'aggravation du risque em cours de contrat, telle que, si les circonstances nouvelles avaient été déclarées lors de la conclusion ou du renouvellement du contrat, l'assureur n'aurait pas contracté ou ne l'aurait fati que moyennant une prime plus élevée, l'assureur a la faculte soit de dénoncer le contrat, soit de proposer um nouveau montant de prime. Dans le premier cas, la résiliation ne peut prendre effet que dix jours après notification et l'assureur doit allors rembourser à l'assuré la portion de prime ou de cotisation afférente à la période pendant laquelle le risqué n'a pas couru. Dans le second cas, si l'assuré ne donne pas suíte à la proposition de l'assureur ou s'il refuse expressément le nouveau montant, dans le délai de trente jours à compter de la proposition, l'assureur peut résilier le contrata au terme de ce délai, à condition d'avoir informe l'assuré de cette faculte, en la faisant figurer en caracteres apparants dans la lettre de proposition". Cf. www.legifrance.gouv.fr/codedesassurances. 
póteses de seguro, em especial o de vida, dispensam a existência de um prejuízo para que o segurado tenha direito ao benefício contratado.

Um segundo problema do âmbito do adimplemento consiste em saber se o pagamento da indenização pode ser feito diretamente ao terceiro, que sofre o prejuízo por força de uma conduta do segurado. A este respeito, nos casos de seguros legalmente obrigatórios, prevê-se a possibilidade de a indenização por sinistro se paga pelo segurador diretamente ao terceiro prejudicado (art. 788).

Cuida-se de preceito sem precedente no direito anterior. A hipótese mais freqüente de seguro obrigatório em nosso ordenamento é o denominado DPVAT, seguro obrigatório de danos pessoais causados por veículos automotores de vias terrestres. Nestes casos, reconhece o Código de 2002 a existência de um direito próprio do terceiro frente ao terceiro, vítima do prejuízo. A conseqüência é a possibilidade de propositura de ação direta da vítima contra o segurador.

Pondere-se que a possibilidade expressa de pagamento diretamente ao terceiro situa-se nos seguros obrigatórios. Debate-se acerca da mesma viabilidade nos seguros facultativos, que no Direito brasileiro representam uma gama maior de abrangência. Não obstante a existência de forte corrente afirmativa ${ }^{84}$, que se baseia no indicado caráter social do contrato de seguro, a jurisprudência do Superior Tribunal de Justiça tem se orientado de modo restritivo, sob o fundamento de que, sendo o seguro facultativo contratado em favor do segurado, e não de terceiro, a presença daquele deve ser exigida no pólo passivo da lide, não sendo possível a demanda intentada diretamente pela vítima somente contra seguradora, diversamente do que ocorre nas hipóteses de seguro obrigatório de responsabilidade civil ${ }^{85}$.

O pagamento da indenização pressupõe o sinistro, que deverá ser informado ao segurado imediatamente. Cuida-se, uma vez mais de dever de cooperação decorrente da boa fé, a ser cumprido pelo segurado. Busca-se evitar que a eventual demora do segurado neste procedimento acarrete prejuízos ao segurador.

Se houver, porém, eventual retardamento do segurado em informar o segurador, esta circunstância não o eximirá do pagamento da indenização ao terceiro. Poderá apenas surgir o direito do segurador de pretender o ressarcimento das despesas adicionais frente ao segurado.

O Código civil contempla outras vedações ao segurado (art. 788): proíbe-se que ele (i) reconheça sua responsabilidade extrajudicialmente, ou, em ação judi-

84 Ver, por exemplo, Pasqualotto, Contratos Nominados iII, p. I49, op. cit.

85 Nesse sentido, cf. o REsp 962 230/RS, Rel. Min. Luis Felipe Salomão, 2 a Seção, j. o8.02.201 2, cuja ementa é a seguinte: "Descabe ação do terceiro prejudicado ajuizada direta e exclusivamente em face da seguradora do apontado causador do dano. No seguro de responsabilidade civil facultativo a obrigação da seguradora de ressarcir danos sofridos por terceiros pressupõe a responsabilidade civil do segurado, a qual, de regra, não poderá ser reconhecida em demanda na qual este não interveio, sob pena de vulneração do devido processo legal e da ampla defesa". Ver também REsp 256.424-SE, Rel. Min. Aldir Passarinho Jr., 4 a Turma, j. 29. I I.2005. 
cial, confesse sua culpa; (ii) transacione com o terceiro prejudicado; (iii) efetue ressarcimento do prejuízo ao terceiro diretamente, sem a concordância expressa do segurador.

Esta orientação merece, porém, uma interpretação congruente, pois não se pode pretender a imposição de condutas desleais ao segurado. $\mathrm{Na}$ hipótese, por exemplo, de ele se considerar culpado por um eventual acidente e reconhecer esta condição, seja na esfera judicial como extrajudicial, o efeito do dispositivo há de ser que esta conduta não vincula o segurador ${ }^{86}$. Da mesma forma, haveria desproporcionalidade na perda do direito à indenização pelo segurado, apenas pelo fato de haver feito pagamento devido ao terceiro. Também aqui há que se adotar a orientação de que o ato não afeta necessariamente o segurador ${ }^{87}$.

Outra questão conexa ao adimplemento revela a preocupação do legislador em resguardar o segurado na hipótese de atraso no pagamento da indenização pelo segurador. Cumpre ponderar que o Código Civil não estabelece um prazo para que o segurador efetue o pagamento da indenização. Desse modo, recorrese à legislação específica, mais precisamente à Circular n. 90, da SUSEP, que, em seu artigo $30, \$ \mathrm{I}^{\circ}$, determina o prazo de 30 dias para a liquidação dos sinistros, após a apresentação de todos os documentos exigidos pelo segurador do segu$\operatorname{rado}^{88}$.

Configurada a mora, seja pelo advento do termo, seja pela notificação realizada pelo segurado, o artigo estabelece duas conseqüências: de um lado, fica assegurada a correção monetária do valor da indenização, a ser feita segundo índices oficiais. De outro, determina-se a incidência de juros moratórios.

No âmbito do seguro, a Lei 5.488/68 previu a correção monetária para o pagamento das indenizações. O Código de 2002 , portanto, ratifica esta orientação. Configurada a mora do segurador, haverá igualmente a incidência de juros mo-

86 A este respeito, cf. a Ap. Civ. n. 700 I8807735, Rel. Des. Cláudio Baldino Maciel, i $2^{\text {a }}$ C. Civ. TJRs: "Responsabilidade civil em acidente de trânsito. Ação de indenização. Dano Material. Confissão expressa dos fatos pelo réu. Sentença procedente. Denunciação à lide. Seguradora. Art. 787 do Código Civil. Alcance. Não pode o o direito 'forçar' alguém a falsear a verdade, deixando de admitir o que realmente ocorreu, sob pena de perder eventual direito que tenha de ver-se ressarcido em face de contrato de seguro. O réu não pode ser forçado a contestar, narrando fatos não verdadeiros, sob pena de não fazer jus a um direito derivado de um contrato. O contrato de seguro, em tal hipótese, não perde sua eficácia porque o segurado deixou de contestar judicialmente fatos que reconhece verdadeiros. Outra fosse a solução, ter-se-ia que admitir que o próprio direito estaria a provocar a má-fé processual, a incentivar a mentira, a promover a defesa estéril de versão capciosa, tudo para assegurar ao autor da induzida vilania processual o direito de regresso contra a seguradora. Não pode a tanto servir o direito, ou será a negação de si mesmo. Apelo não provido".

87 Nesse sentido, Ernesto Tzirulnik/Flávio de Queiroz Cavalcanti, Ayrton Pimentel, $O$ Contrato de Seguro, p. I44. A orientação encontra-se no Enunciado 373, do CEJ.

88 Saliente-se que o $\$ 2^{\circ}$, do artigo 30 , da Circular 9o, da SUSEP, prevê a possibilidade de o segurador solicitar novos documentos do segurado. Nesta hipótese, ocorrerá a suspensão do prazo para pagamento da indenização. 
ratórios sobre a indenização. Trata-se, agora, de penalidade imposta ao devedor, por força do atraso no pagamento.

As conseqüências previstas neste artigo para o caso de mora do segurador não impedem que o segurado pleiteie perdas e danos. Trata-se de possibilidade expressamente assegurada pelo artigo 475 , do Código Civil ${ }^{89}$. Ao cobrar a dívida não paga pelo segurador, portanto, poderá o segurado cumular este pedido com o de indenização. Mas é seu o ônus de provar o prejuízo efetivamente sofrido pelo atraso, tais como dano emergente e lucro cessante. $\mathrm{Na}$ jurisprudência, porém, tem sido afastada a concessão de dano moral em decorrência do mero inadimplemento de dívida.

\section{B. A sub-rogação do segurador na posição jurídica do segurado}

Uma conseqüência relevante do cumprimento pelo segurador de seu dever principal consiste no direito à sub-rogação pelo segurador (art. 786), isto é, ele ocupa a posição jurídica deste em toda a sua extensão no que concerne ao contrato de seguro - com exceção à hipótese do seguro de pessoa. Trata-se de um caso de sub-rogação pessoal - em face da imposição da lei, configura-se no caso uma situação de sub-rogação legal.

O tema da sub-rogação do segurador mereceu regulação legal no já no Código Comercial (art. 728) de ı 850, relativamente aos seguros marítimos ${ }^{\circ \circ}$. Tratase de disposição, porém, sem correspondência no Código Civil de i9r6, o que desencadeou aceso debate no ordenamento brasileiro se seria possível aplicar ao seguro a regra da sub-rogação legal, prevista no art. 985 , $\mathrm{III}^{9 \mathrm{I}}$, do direito anterior ${ }^{92}$.

Argumentava-se que o segurador era remunerado pelo prêmio pago pelo segurado, razão pela qual não haveria fundamento econômico-jurídico para que se voltasse ainda contra o causador do dano. Em essência, o segurador pagaria dívida própria e não alheia, de modo que não se configuraria situação de subrogação legal93.

89 Art. 475. "A parte lesada pelo inadimplemento pode pedir a resolução do contrato, se não preferir exigir-lhe o cumprimento, cabendo, em qualquer dos casos, indenização por perdas e danos".

90 "Pagando o segurador um dano acontecido à coisa segura, ficará sub-rogado em todos os direitos e ações que ao segurado competirem contra terceiro; e o segurado não pode praticar ato algum em prejuízo do direito adquirido dos seguradores".

9I Art. 985: "A sub-rogação opera-se, de pleno direito, em favor: [...] III - Do terceiro interessado, que paga a dívida pela qual era ou podia ser obrigado, no todo ou em parte".

92 Ver, por exemplo, WaGner Barreira, Sub-rogação do segurador, in Estudos furídicos em Homenagem ao Professor Orlando Gomes, pg. 143 e segs., Rio de Janeiro, I979.

93 Ver, por exemplo, Konder Comparato, O Seguro de Crédito, p. I55, op. cit. 
Na jurisprudência, houve discussão sobre a possibilidade de configurar-se a sub-rogação, que culminou com a solução afirmativa, cristalizada na Súmula n. I88, do Supremo Tribunal Federal94. O tema mereceu ratificação legal, ainda ao tempo do Código de igi6, mediante o artigo $8^{\circ}$, da Lei 6.194/74, referente ao seguro obrigatório de automóveis ${ }^{95}$.

Nesse contexto, portanto, que o artigo 786 estendeu, a todos os casos de seguro de dano, a possibilidade de sub-rogação ao segurador. Excetuou-se, apenas, os seguros de pessoa, em face de previsão expressa no artigo 80o. Em síntese, prevalece a fundamentação, correta, que ratifica o caráter de indenização do seguro, e pretende impedir que o segurado receba duplo pagamento, de um lado, do segurador; de outro, do terceiro, causador do dano. Além disso, haveria a possibilidade de o terceiro, causador do dano, sair impune de sua conduta ilícita, caso o segurado não investisse contra ele. Acrescente-se que a possibilidade existir sub-rogação, em tese, pode configurar fundamento para a diminuição dos custos da operação securitária ${ }^{96}$.

$\mathrm{O}$ alcance da sub-rogação cinge-se ao valor da indenização paga ao segurado, mas abrange todos os direitos e ações deste frente ao terceiro, como, por exemplo, honorários de advogado, tema já objeto da Súmula n. 257, do Supremo Tribunal Federal97.

Em face da diretriz do preceito, a questão de saber se o sub-rogado, no caso o segurador, poderia ter direitos distintos relativamente ao primitivo credor, o segurado, como no tema do prazo prescricional, perde relevo. Ao tempo do Código de I9ı6, debatia-se o prazo prescricional, caso a sub-rogação decorre-se por força de previsão específica relativa ao contrato de seguro ${ }^{9}$, ou decorreria da previsão da regra relativa à sub-rogação legal (hoje no artigo 346)99.

94 "O segurador tem ação regressiva contra o causador do dano, pelo que efetivamente pagou, até o limite previsto no contrato de seguro".

95 "Comprovado o pagamento, a sociedade seguradora que houver pago a indenização poderá, mediante ação própria, haver do responsável a importância efetivamente indenizada".

96 Nesse sentido, Pontes de Miranda, Tratado de Direito Privado, v. 45, \$ 4.928, op. cit.; Ruben Stiglitz, Derecho de Seguros, vol. II, pg. 47 I, Buenos Aires.

97 Súmula n. 257, do Supremo Tribunal Federal: "São cabíveis honorários do advogado na ação regressiva do segurador contra o causador do dano".

98 A este respeito, ver o seguinte precedente na jurisprudência do stJ: "Contrato de Seguro. Subrogação. Cobrança do valor da apólice. I. Sub-rogada a autora nos direitos decorrentes do contrato de seguro, a ação para cobrar o valor estipulado na apólice prescreve no prazo previsto no art. I 78, \$6 $6^{\circ}$ II, do Código Civil. 2. Recurso Especial não conhecido” (REsp 298406/DF, Rel. Min. Carlos Alberto Menezes Direito, 3 Turma, j. I 5.IO.200 I).

99 Esta orientação encontra-se na jurisprudência do Superior Tribunal de Justiça, que, recentemente, ao tratar de caso regulado ainda pelo Código Cível de i9 i6, considerou que o prazo prescricional aplicável ao sub-rogação, não seria o da prescrição ânua do art. I $78, \S 6^{\circ}$, II, do Código Civil de r9ı6, e sim o prazo relativo à legislação de transporte aero internacional. Cf. REsp i i62649, Rel. para o acórdão Min. Antonio Carlos Ferreira, j. 20 i 4. 
Por força da redação expressa do artigo 786, a ação do segurador contra o terceiro prescreve no mesmo período que a do segurado. Trata-se da solução mais apropriada, correspondendo à acepção estrita da sub-rogação, em que o segurador ocupa a mesma posição jurídica que o segurado frente ao terceiro. Solução distinta configuraria um privilégio a quem se sub-roga.

Cumpre destacar que a sub-rogação pressupõe o pagamento da indenização pelo segurador. Este é o requisito essencial a ser demonstrado pelo segurador, a fim de pretender o direito à sub-rogação - a par da configuração do ilícito. Não se exige, portanto, a apresentação do contrato de seguro para a eventual ação regressiva contrato o terceiro causador do dano ${ }^{\mathrm{IOO}}$.

Tendo em vista que o pagamento pelo segurador é o pressuposto para a subrogação, será a partir desta data que incidirá a correção monetária da quantia adimplida, em caso de ação regressiva pela seguradora contra o terceiro causador do dano ${ }^{\mathrm{IOI}}$.

Pondera-se que se o ato do segurado consistir em receber o pagamento do causador do dano, antes do recebimento da indenização do segurador, não se configura a sub-rogação, na medida em que foi extinta a obrigação ${ }^{\mathrm{IO} 2}$. Situação distinta, porém, ocorre se o segurado recebe do terceiro após o recebimento da indenização pelo segurador. Neste caso, há que se verificar se o pagamento pelo terceiro foi feito de boa fé, situação em que será considerado perfeito o pagamento, ou se pagou de má fé, condição em que manterá sua responsabilidade ${ }^{\mathrm{IO} 3}$.

\section{Conclusão}

No âmbito da exposição feita sobre o desenvolvimento do contrato de seguro, e após a sumária análise de algumas questões controvertidas sobre sua estrutura e desenvolvimento, pode-se apontar algumas tendências sobre o tema.

Primeiramente, sobressai a tentativa do codificador civil de 2002 de consolidar algumas disposições relativas ao contrato de seguro, que por força da

ioo Trata-se de orientação já existente na doutrina (Pontes de Miranda, Tratado de Direito Privado, v, 45, $\$ 4928$, op. cit.) e na jurisprudência anteriores ao Código de 2002: "Acidente de trânsito. Seguradora. Sub-rogação. Tendo a seguradora pago o sinistro, em documento circunstanciado e suficiente para exercer a sub-rogação, não cabe a exigência de que traga aos autos a apólice e documentos destinado ao segurado". Ap. Civ. n. 700000888 I 5 , Rel. Des. Cezar

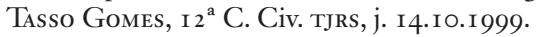

io I Nesse sentido, cf AgRg no Ag ior 07 I 5/RS, Rel. Min. Sidnei Benetti, 3 a Turma, j. i 6.04.2009: "Agravo Regimental. Responsabilidade Civil. Contrato de Seguro. Insuficiência dos documentos juntados à inicial. Reexame do conjunto fático-probatório. Impossibilidade. Súmula 7/sTJ. Juntada de contrato. Dissídio não comprovado. Ação regressiva movida pela seguradora contra o causador dos danos. Correção monetária. Termo inicial. Data do desembolso da quantia”.

IO2 Ver a respeito, o REsp i $27656 / D F$, Rel. Min. Barros Monteiro, 4 a Turma, DJu, 25.03.2002.

io3 Ver, por exemplo, Ernesto Tzirulnik/Flávio de Queiroz Cavalcanti/Ayrton Pimentel, $O$ Contrato de Seguro, p. I 30 , op. cit. 
defasagem da codificação anterior, de ı9ı6, não contemplava mais o núcleo das disposições sobre o negócio jurídico de seguro. Vislumbra-se uma perda de relevância do Código em face do grande número de determinações administrativas oriundas das instâncias administrativas - sendo a mais importante a citada Superintendência de Seguros Privados.

Houve, igualmente, um esforço da codificação para atualizar a visão técnica e doutrinária sobre o contrato de seguro, em especial, como desde logo afirmado no texto, no sentido de situá-lo como negócio visando à garantia frente aos riscos, e com isso retirando-o do quadro puro e simples da percepção de que o pagamento do seguro constitui um ato de ressarcimento. Permanece em aberto, porém, se esta mudança de concepção teórica possui e exerce alguma relevância no campo prático.

Relativamente ao desenvolvimento do contrato de seguro, sobretudo nos pontos elegidos para exame no texto, vislumbra-se um visível distanciamento entre a concepção clássica do legislador e a orientação jurisprudencial.

Há que se destacar - no âmbito da conclusão - a visão protetiva dos tribunais brasileiros relativamente ao segurado, seja para abrandar as conseqüências da mora na hipótese de não pagamento do prêmio, seja para relativizar as hipóteses e a extensão do seu dever de informar.

A visão central da jurisprudência brasileira repousa, de um lado, sobre o caráter social do contrato de seguro (contrato normalmente de consumo) e, de outro, sobre a concepção de que o seguro, na atualidade, tem caráter comutativo. Os riscos estariam integralmente computados pelo segurador, razão pela qual não se deveria julgar eventuais violações do segurado, quanto a seus deveres, de forma rígida.

Se é certo que esta concepção tem hoje prevalência no Direito Privado brasileiro, há que se igualmente ponderar que ela contém em si um risco dúplice: onerar o segurado, na medida em que a seguradora reproduz nos seus custos a oneração decorrente das posições jurisprudências; de outro, a liberalidade jurisprudencial no exame das condutas dos segurados pode conduzir a uma leniência social - e isto é visível no que concerne ao problema da direção com embriaguez.

Ambos os riscos devem, contemporaneamente, ser objeto do crivo doutrinário, a fim de propor uma constante reflexão à jurisprudência, para que o risco percebido não conduza prejuízos sociais.

\section{Bibliografia}

Ascarelli, Tulio. O conceito unitário do contrato de seguro, in Problemas das Sociedades Anônimas e Direito Comparado, Saraiva, I969.

Argiroffi, Alessandro \& Luisa Avitabile, Responsabilità, rischio, diritto e postmoderno - Percorsi di Filosofia e fenomenologia giuridica e morale, Giappicheli, Torino, 2008. 
Barreira, Wagner. Sub-rogação do segurador, in Estudos furídicos em Homenagem ao Professor Orlando Gomes, pg. I43 e segs., Rio de Janeiro, I979.

Beck, Ulrich. Sociedade de Risco: rumo a uma outra modernidade, São Paulo, 20 Io, no original, Risikogesellschaft, München, I986.

Borges, Nelson. A Teoria da Imprevisão e os Contratos Aleatórios, in RT 782/,pg. 78 e segs.

Cian/Trabucchi, Commentario breve al codice civile, artigo i 882 do Código civil italiano, pg. I883, ítem IV, 3a. ed., I988, CEDAM.

De Almeida Costa, Mario Júlio. Direito das Obrigações, $6^{\mathrm{a}}$ ed., Almedina.

Da Silva, Ovídio Araújo Baptista. O Seguro como Relação furídica Comunitária, in Seguros: uma questão atual, Max Limonad, $200 \mathrm{I}$.

Deda de Abreu, Virgína Duarte. O inadimplemento no pagamento do prêmio no contrato de seguro em face do novo código civil, in RT 824/24.

De Passos, J.J. Calmon. O risco na Sociedade Moderna e seus reflexos na Teoria da Responsabilidade Civil e na Natureza furídica do Contrato de Seguro, in I Foro de Direito do Seguro - Anais, Max Limonad, 200 I, pg. I I e segs.

Delgado, José Augusto. Comentários ao Novo Código Civil, vol. xi, pg. I 7o, Forense, 2004 .

Ewald, François. Risco, Sociedade e Fustiça, in II Foro de Direito do Seguro, pg. 28, Instituto Brasileiro do Direito do Seguro, 2002.

Galgano, Francesco. La Globalización en el espejo del derecho, Rubinzal-Culzoni, 2005 .

Halperin, Isaac. Contrato de Seguro, Buenos Aires, i946.

Heun, W. Staatliche Risikosteuerung und Verfassung, in RW 20 I I, pg. 376 e segs.

Konder Comparato, Fábio. O Seguro de Crédito, rt, i 968.

Konder Comparato, Fábio. Substitutivo ao Capitulo Referente ao Contrato de Seguro no Anteprojeto de Código Civil, in Revista de Direito Mercantil, vol. 5, I972. 
Konder Comparato, Fábio. Seguro de garanti de obrigações contratuais, in Novos ensaios e pareceres de Direito Empresarial, Forense, Rio de Janeiro, I98 I, pg. 35 I, 353 .

La Torre, Antonio. Le Assicurazioni, Giuffrè, 2000.

Monti, Alberto. Buona fede e Assicurazione, Giuffrè, 2002.

Nicolas, Véronique. Essai d'une Nouvelle Analyse du Contrato d'Assurance, Lgdj, I996.

November, András \& Valérie November, Risque, assurance et irréversibilité, in Révue européenne des sciences sociales, 2004, pg. I6I e segs.

Polido, Walter. Da limitação da autonomia privada nas operações de seguros: coletivização dos interesses - Nova perspectiva social e jurídica do Contrato de Seguro, in Revista de Direito do Consumidor, vol. 74, 2010, pg. 74 e segs.

Romano Martinez, Pedro \& Pedro Fuzeta da Ponte, Garantias de Cumprimento, Almedina, $4^{\text {a }}$ ed., 2003.

Scwintowski, Hans-Peter. Die Rechtsnatur des Versicherungsvertrags, in furistische Zeitung, I4/I996.

Stiglitz, Ruben. Derecho de Seguros, vol. in, Buenos Aires.

Tzirulnik, Ernesto, Fláviode Queiroz B. Cavalcanti \& Ayrton Pimentel, $O$ Contrato de Seguro de acordo com o Novo Código Civil Brasileiro, $2^{\mathrm{a}}$ ed., Revista dos Tribunais, 2003. 